\title{
Studentská hodnocení výuky s využitím dotazníku CEQ: analýza zahraničních zkušeností
}

\author{
Kateřina Juklováa, Martin Chvál ${ }^{b}$, Stanislav Micheka, \\ Jindra Vondroušováa \\ a Univerzita Hradec Králové, Pedagogická fakulta \\ ${ }^{\mathrm{b}}$ Univerzita Karlova, Pedagogická fakulta
}

Redakci zasláno 17. 12. 2018 / upravená verze obdržena 10. 9. 2019 /

/ k uveřejnění přijato 28. 10. 2019

\begin{abstract}
Abstrakt: Přehledová studie si klade za cíl představit jeden z celosvětově nejvyužívanějších dotazníků $\mathrm{k}$ hodnocení výuky studenty, Course Experience Questionnaire (CEQ). V úvodním oddíle studie seznamuje s teoretickým zázemím vzniku a úprav dotazníku. Na základě analýzy 103 empirických a přehledových studií popisujících zkušenosti s tvorbou, ověřováním i využíváním dotazníku v různých vzdělávacích kontextech a ve více než 20 zemích světa přináší doklady o jeho psychometrických vlastnostech a možnostech využití. Diskutován je potenciální přínos dotazníku pro studentské evaluace v aktuálních podmínkách českého vysokého školství.
\end{abstract}

Klíčová slova: přehled, CEQ dotazník, vnímaná kvalita výuky, studijní zkušenost, teorie studentova učení, vysokoškolské vzdělávání

Kvalita výuky jako jedna z prioritních činností vysokoškolských institucí je v České republice regulována prostřednictvím udělování akreditací. V souladu s podmínkami Národního akreditačního úřadu ČR jsou vysokoškolské instituce aktuálně povinny dokládat zprávu o zajištování kvality vzdělávací činnosti. Studentská hodnocení vysokoškolské výuky, která jsou součástí autoevaluačních aktivit, jsou v českých podmínkách obecně uznávanou, ale zároveň poměrně citlivou, a ne vždy systematicky praktikovanou záležitostí, na což je již po dlouhou dobu poukazováno (např. Vašutová, 2002; Mareš \& Došlá, 2008). Za zdroje potenciálních i reálných komplikací jsou obecně považovány problematická konstrukce samotných kritérií evaluace, otázky validity studentských výpovědí i práce s výsledky a jejich využívání (Mareš \& Ježek, 2013). Důkazy o tom, že zdaleka nejde o české specifikum, uvádějí rovněž zahraniční zdroje (Simpson \& Siguaw, 2000; Arthur, 2009), popisující např. plošné zavádění evaluací v 80. letech v USA, od něhož se později ustupovalo pro napětí, které $\mathrm{v}$ akademických kruzích mezi studenty a pedagogy vyvolávalo. Podobný vývoj je možné sledovat i v dalších západních zemích, z nichž jmenujme např́klad Finsko (Young \& Shaw, 1999). 
Navzdory těmto obtížím množství empirických studií z oblasti evaluace vysokoškolské výuky ze zahraničí dokládá, že zájem o studentskou perspektivu neustává, ale naopak roste. V procesu zavádění nástrojů pro studentská hodnocení výuky do celkové autoevaluační strategie instituce hraje důležitou roli vyjasněnost funkcí, které má plnit, a návaznost na vnitřní systémy zajištování kvality, které umožní smysluplné využívání získaných dat. Má-li se instituce na výsledky těchto hodnocení spolehnout a využívat je jako validní indikátory pro rozhodování o svém dalším rozvoji, potřebuje znát rovněž teoretická východiska, na jejichž základech nástroj vznikl, a jeho psychometrické vlastnosti, zejména má-li být využíván ke kvantifikaci (Barrie, Ginns, \& Prosser, 2005).

Vzhledem k tomu, že nástroje dosud využívané pro hodnocení vysokoškolské výuky studenty v podmínkách českých vysokých škol jsou obvykle dotazníky a škály vlastní konstrukce sledující množství značně různorodých a teoreticky nevyjasněných indikátorů a existence validovaného nástroje použitelného pro hodnocení výuky studentem vysoké školy nám není známa, jednou $\mathrm{z}$ možností, která se $\mathrm{v}$ rámci hledání možností validního a spolehlivého hodnocení vysokoškolské výuky nabízí, je pokusit se adaptovat instrument zahraniční. Dotazník CEQ (Course Experience Questionnaire), na který se $\mathrm{v}$ tomto příspěvku zaměřujeme, je podle nás jedním z možných kandidátů na adaptaci a využívání také v prostředích českého vysokého školství. Jak vyplývá z přehledové studie Spoorena, Brockxe a Mortlemanse (2013), společně s dotazníky IDEA (Cashin \& Perrin, 1978) a SEEQ (Marsh, 1982) patří CEQ mezi několik málo celosvětově známých a využívaných validovaných instrumentů k hodnocení výuky studenty, které se vyznačují jasnou teoretickou strukturou. Dalšími důvody našeho zájmu o CEQ jsou skutečnosti, že dotazník má v originální verzi vysoce uspokojivé psychometrické vlastnosti a že existují doklady o jeho úspěšné adaptaci pro využití ve vysokém školství v mnoha zemích světa. $V$ neposlední řadě k našemu zájmu přispěl fakt, že existuje více verzí využitelných na různých úrovních hodnocení a k různým účelům a rovněž byly publikovány zkušenosti se zaváděním zpětné vazby získané dotazníkem CEQ do vnitřních systémů zajištování kvality vysokoškolské výuky (Lizzio, Wilson, \& Simons, 2002; Ginns \& Barrie, 2004; Barrie, Ginns, \& Prosser, 2005; Barrie \& Ginns, 2007; Talukdar, Aspland, \& Datta, 2013).

Záměrem našeho př́spěvku je tedy představit dotazník CEQ analyzovat výsledky generované dotazníkem z dostupných studií a na základě těchto zjištění diskutovat potenciální přínos CEQ pro hodnocení výuky studenty 
v českém vysokém školství a v neposlední řadě rovněž upozornit na možná úskalí pramenící z jeho využívání. $\mathrm{V}$ rámci diskuse zjištěných výsledků se zaměříme na dvě otázky:

01: V čem může být pro naše prostředí a podmínky dotazník CEQ obohacující?

02: Z jakých aspektů dotazníku mohou naopak pramenit omezení pro validní a spolehlivé hodnocení výuky studentem $v$ českém vzdělávacím prostředí?

V následující kapitole bude dotazník CEQ představen, ve druhé kapitole se zaměříme na analýzu dostupných studií z hlediska stanovených kritérií a v závěru bude diskutován potenciální přínos a využitelnost dotazníku pro hodnocení vysokoškolské výuky studenty v českých podmínkách.

\section{Dotazník CEQ: kontext vzniku, teoretická východiska a psychometrie originální verze}

\subsection{Kontext vzniku a teoretická východiska}

Course Experience Questionnaire (CEQ) byl vytvořen Paulem Ramsdenem začátkem 90. let v Austrálii. Jeho vznik je zasazen do období růstu nároků na efektivitu a akontabilitu univerzitních institucí, od nichž byly požadovány důkazy o míře a způsobech, jakými plní své cíle (Linke, 1991). Pro jejich vyjádření byly utvářeny systémy indikátorů kvality, které sloužily k několika účelům - $\mathrm{k}$ porovnávání výkonnosti různých institucí, k hodnocení změn v čase a pro měření pokroku (Talukdar, Aspland, \& Datta, 2013). CEQ se stal jedním z podkladů pro tyto systémy.

Autor dotazníku staví na výzkumech učení vysokoškolských studentů, které se staly součástí tzv. teorie studentova učení (SLT). Jádrem teorie jsou strategie, které student zapojuje v průběhu učení, konceptualizované jako studentovy prístupy $k$ učení (students, approaches to learning, SAL). V jejich rámci byly identifikovány dva odlišné př́stupy, učení hloubkové (deep learning) a povrchové (surface learning) (Marton \& Saljö, 1976; Biggs, 1989; Marton \& Pang, 2006). Hloubkové učení se projevuje záměrem učivu porozumět a využíváním takových kognitivních strategií, které vedou ke smysluplnému učení (např́iklad aktivní analyzování konceptů a vysoká úroveň elaborace učiva), zatímco pro učení povrchové (surface learning) je typické úsilí dosáhnout cíle s minimem vynaložené energie a využívání rutinních strategií (např. nereflektovaná memorizace nebo opakování), které vedou pouze k omezenému 
porozumění. Kvalitní učení bylo empiricky doloženo jako učení hloubkové, oproti tomu učení povrchové se prokázalo jako nežádoucí, nebot' nevede k trvalým a žádoucím studijním výsledkům (Ramsden \& Entwistle, 1981; Entwistle \& Ramsden, 1983; Biggs, 1989; Marton \& Pang, 2006).

Biggsův model učení (1989), označovaný jako Model 3P, který rozlišuje mezi vstupními (presage), procesuálními (process) a výslednými (product) proměnnými, lokalizuje př́istupy k učení mezi procesy objevující se jako odpověd' na interakci vstupních proměnných (studentovy předchozí znalosti, osobnostní charakteristiky a charakteristiky studijního prostředí) a ovlivňující výsledky učení (průměrný studijní prospěch, přenositelné dovednosti atp.).

Konstrukt měřený dotazníkem CEQ označovaný jako studijní zkušenost, percepce výuky nebo hodnocení kvality výuky je možné umístit mezi vstupní (presage) proměné a procesy (process) do Rozšířeného 3P modelu učení (Trigwell \& Prosser, 1996; viz Obrázek 1). Ten mezi vstupní proměnné a studentovy př́stupy $\mathrm{k}$ učení včlenil kategorii označovanou jako studentovo vnímání kontextu. Kategorie je předpokládaným a potvrzeným zdrojem odlišností studentů v přístupech k učení a ve studijních výsledcích (Säljö, 1979). Její pozice a vztahy v rámci celého modelu umožňují vystihnout to, co dotazník CEQ měří. Není zprávou o vyučovací realitě samotné, ale výpovědí konkrétních studentů o tom, jak konkrétní studijní realitu vnímají v určitém čase, což se prokázalo jako významně související s jejich procesy a výsledky učení (Ramsden \& Entwistle, 1981; Trigwell \& Prosser, 1991; Trigwell \& Prosser, 1996; Lizzio et al., 2002). Percepce výuky studenty byly zároveň potvrzeny jako související s kvalitativně odlišnými způsoby, jakými studenti reprezentují procesy učení, označované některými autory jako koncepce učení (např. Säljö, 1979; van Rossum \& Taylor, 1987; Landbeck \& Mugler, 1994; Beaty, Dall'Alba, \& Marton, 1997). Výzkumně bylo potvrzeno, že tyto koncepce mají vývojový trend a vztahují se k epistemickému a intelektuálnímu vývoji (Perry, 1970; van Rossum \& Taylor, 1987). Tyto souvislosti mimo jiné implikují, že kontext výuky, který je studenty vnímán a hodnocen jako kvalitní, respektuje jejich osobní charakteristiky (původní znalosti, schopnosti, motivaci apod). Výuka vnímaná studenty jako kvalitní zároveň vede k zapojování hloubkových př́ístupů k učení (Ramsden \& Entwistle, 1981; Trigwell \& Prosser, 1991; Trigwell \& Prosser, 1996). 
$\begin{array}{rrr}\begin{array}{r}\text { Vstupní proměnné } \\ \text { (PRESAGE) }\end{array} & \begin{array}{r}\text { Procesuální proměnné } \\ \text { (PROCESS) }\end{array} & \begin{array}{r}\text { Výsledné proměnné } \\ \text { (PRODUCT) }\end{array}\end{array}$

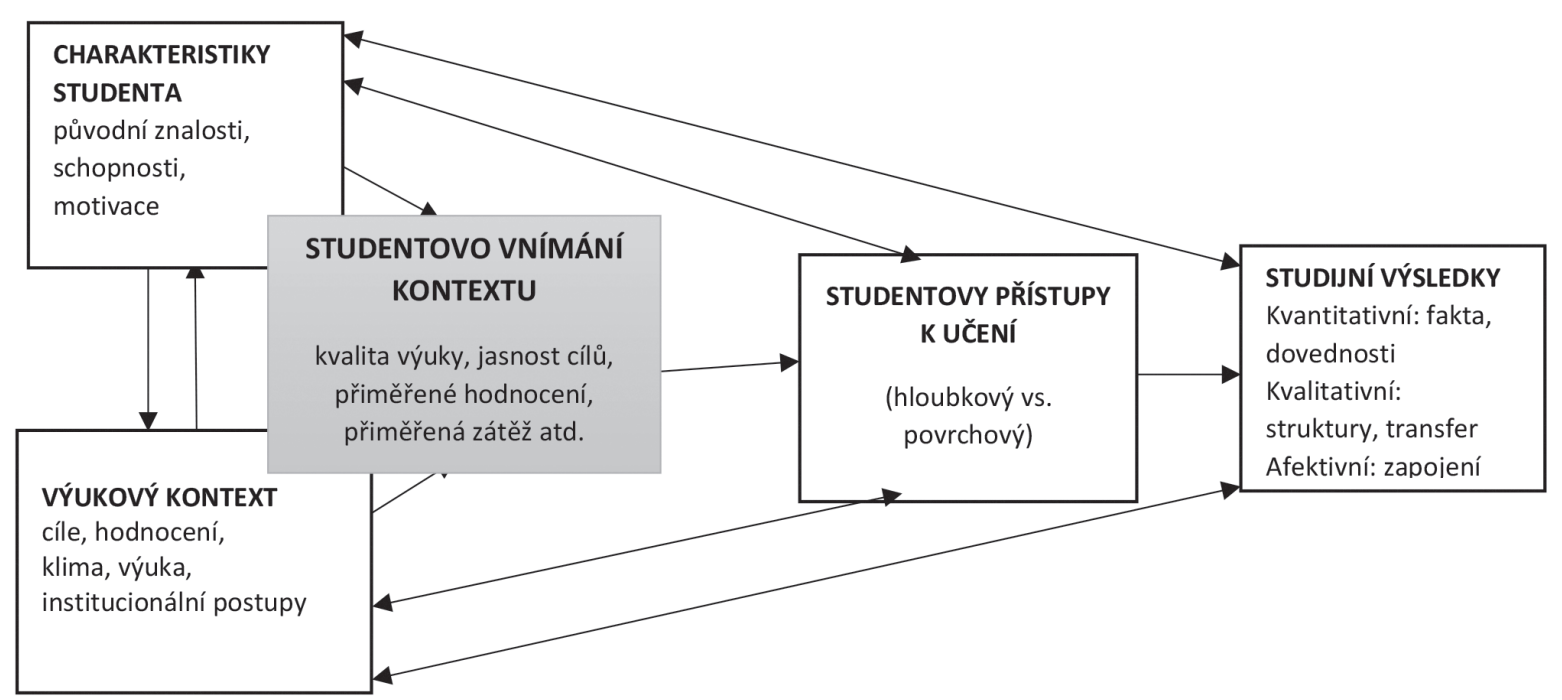

Obrázek 1. Rozšířený 3P model vyučování a učení (volně podle Trigwell \& Prosser, 1996).

V rámci studentova vnímání výukového kontextu bylo empiricky potvrzeno více aspektů s významným dopadem na př́ístupy k učení. Gaff, Crombag a Chang (1976) a Ramsden (1979) se např́íklad shodli ve zjištění, že mezi tyto aspekty patří vztahy učitele se studenty, závazek učitele k vyučování, míra studijní zátěže, používané vyučovací metody, relevance výuky ve vztahu k budoucí profesi, sociální klima ve studijní skupině, jasnost cílů a standardů a míra svobody v učení. Ramsden a Entwistle (1981) dále zjistili, že u studentů, kteří vnímali výuku jako jasně strukturovanou a zároveň podpůrnou, byla významně větší pravděpodobnost, že porozumí struktuře a obsahu kurikula. Oproti tomu studenti, kteří výuku označili jako nadměrně náročnou a zatěžující a bez možnosti volby metod a obsahu, s větší pravděpodobností zaujímali povrchové př́ístupy k učení založené na záměru uspokojit pouze požadavky hodnocení.

Tato zjištění položila základy škál několika dotazníků, považovaných za předchůdce CEQ. Tím nejvlivnějším byl Course Perception Questionnaire (CPQ) vytvořený Ramsdenem a Entwistlem (1981) jako výzkumný nástroj k měření zkušenosti britských studentů v konkrétních studijních programech 
a odděleních (Elphinstone, 1990). Dalšími dvěma zdroji, z něhož CEQ čerpal, byly dotazníky SEQ: School Experiences Questionnaire (Ramsden, Martin, \& Bowden, 1989) a ESHE: Experiences of Studying and Higher Education (Entwistle \& Tait, 1990).

První verze CEQ obsahovala 80 položek sytících 9 škál, z ní po úpravách vzešla 57položková verze s 8 škálami, později dále krácená o 11 položek při zachování 8 stejnojmenných škál (Elphinstone, 1990). Verze použitá ve zkušebním národním šetření pro testování CEQ jako potenciálního indikátoru výkonu vysokoškolských institucí v oblasti výuky zahrnovala 30 položek sytících pět škál (Linke, 1991; Ramsden, 1991):

1) dobrá výuka (8 položek);

2) jasné cíle (5 položek);

3) přiměřená zátěž ( 5 položek);

4) přiměřené hodnocení (6 položek);

5) důraz na nezávislost (6 položek).

Porovnání struktury prvních tří verzí dotazníku CEQ s verzí použitou v národním testování shrnuje tabulka 1 . Oproti ostatním verzím postrádá CEQ30 škály Závazek k akademickému výkonu, Kooperace/kompetitivnost a tři původní škály tvořící Dobrou výuku byly sloučeny do jedné.

Tabulka 1

Porovnání struktury prvních tří verzí dotazníku CEQ s verzí použitou $v$ národním testování

\begin{tabular}{llll}
\hline $\begin{array}{l}\text { Škály první verze: CEQ80 } \\
\text { (Elphinstone, 1990) }\end{array}$ & $\begin{array}{l}\text { Škály druhé a třetí } \\
\text { verze: CEQ57 a CEQ46 } \\
\text { (Elphinstone, 1990) }\end{array}$ & $\begin{array}{l}\text { Škály verze použité } \\
\text { v národním šetření: } \\
\text { CEQ30 (Ramsden, 1991) }\end{array}$ \\
\hline $\begin{array}{l}\text { Dobrá výuka: enthusiasmus } \\
\text { a zájem }\end{array}$ & Dobrá výuka - explanace & Dobrá výuka \\
\hline 2 & $\begin{array}{l}\text { Dobrá výuka: dostupnost studijni } \\
\text { podpory }\end{array}$ & $\begin{array}{l}\text { Dobrá výuka - dostupnost } \\
\text { a studijní podpora }\end{array}$ & \\
\hline 3 & $\begin{array}{l}\text { Dobrá výuka: množství a kvalita } \\
\text { zpětné vazby na práci studentů }\end{array}$ & $\begin{array}{l}\text { Dobrá výuka - zpětná } \\
\text { vazba }\end{array}$ & \\
\hline 4 & Jasné cíle, standardy a struktura & $\begin{array}{l}\text { Jasné cíle, standardy } \\
\text { a podpora }\end{array}$ & Jasné cíle a standardy \\
\hline 5 & Zátěž & Zátěž & Přiměřená zátěž \\
\hline
\end{tabular}




\begin{tabular}{llll}
\hline $\begin{array}{l}\text { Škály první verze: CEQ80 } \\
\text { Elphinstone, 1990) }\end{array}$ & $\begin{array}{l}\text { Škály druhé a třetí } \\
\text { verze: CEQ57 a CEQ46 } \\
\text { (Elphinstone, 1990) }\end{array}$ & $\begin{array}{l}\text { Škály verze použité } \\
\text { v národním šetření: } \\
\text { CEQ30 (Ramsden, 1991) }\end{array}$ \\
\hline 6 & Závazek k akademickému výkonu & $\begin{array}{l}\text { Závazek k akademickému } \\
\text { výkonu }\end{array}$ & \\
\hline 7 & Hodnocení & Hodnocení & Přiměřené hodnocení \\
\hline 8 & $\begin{array}{l}\text { Důraz na studentovu nezávislost } \\
\text { a volbu }\end{array}$ & $\begin{array}{l}\text { Důraz na nezávislost } \\
\text { a volbu }\end{array}$ & Důraz na nezávislost \\
\hline 9 & Kooperace/kompetitivnost & & \\
\hline
\end{tabular}

Tři z pěti škál 30položkové verze CEQ korelují s hloubkovými přístupy k učení (Dobrá výuka, Jasné cíle a standardy a Důraz na nezávislost), zbývající dvě (Přiměřená zátěž a Přiměřené hodnocení) $s$ př́ístupy povrchovými (Ramsden, 1991).

Dobrá výuka (DV) v CEQ30 zahrnuje studentovo vnímání kvality výkladu a zájmu učitelů o to, jak si student vede (např. „Vyučující uměli látku dobře vysvětlit“ a „Vyučující běžně poskytují užitečnou zpětnou vazbu na to, jak si vedete"). Škála Jasné cíle a standardy (JCS) vystihuje míru vnímané jasnosti a srozumitelnosti v tom, co se student má učit a jaká úroveň výsledků se od něho očekává (např. „Standard toho, co se od studentů ve výuce očekávalo, byl dobře známý"). Přiměřená zátěž (PZ) vystihuje míru pocitovaného tlaku na studenta (např. „Objem učiva, který bylo třeba zvládnout, byl takový, že látku nešlo zcela pochopit"), Přiměřené hodnocení (PH) je konceptualizováno jako hodnocení zaměřené na zjišt'ování porozumění versus zjištování zapamatovaného (např. „Vyučující se zajímali více o testování toho, co jsem si zapamatoval/a, než toho, co jsem pochopil/a“) a konečně škála Důraz na nezávislost (DN) zjištuje míru, do jaké výuka podporuje studentovu autonomii (např. „Studenti zde mají hodně možností volby v práci, kterou musí dělat").

K těmto pěti škálám byla připojena jedna samostatná položka, v níž má student vyjádřit celkovou spokojenost s výukou („Celkově jsem s výukou spokojen/a“), která byla využita k validizaci ostatních škál.

\subsection{Psychometrické charakteristiky CEQ30}

V rámci národní zkoušky CEQ v roce 1991 bylo získáno 3372 kompletních odpovědí studentů posledního ročníku 13 vysokoškolských institucí, velkých technologických institutů a vysokých škol dalšího vzdělávání (návratnost dotazníků byla $60 \%$ ). Tato data byla doplněna dalším souborem odpovědí 
(N = 1087) od studentů účetnictví získaných ve stejném roce. Exploratorní faktorová analýza s extrakcí metodou hlavních komponent a šikmou rotací identifikovala obdobnou škálovou strukturu rozvíjenou v předchozích pilotních studiích. Soubor studentů účetnictví reprezentovaný školami z tzv. druhého sektoru, které získaly statut univerzity až v roce 1987, vykazoval velmi podobné výsledky jako první část souboru. Vnitřní konzistence škál vyjádřená skórem Cronbachovo alfa se pohybovala mezi 0,87 a 0,71 (konkrétně: DV 0,87; JCS 0,80; PZ 0,77; PH 0,71 a DN 0,72).

Validita dotazníku byla potvrzena trojím typem vnějšího kritéria - kvalitou procesů učení studentů, spokojeností studentů s výukou a hodnocením předmětů vyučujícími. Kvalita učení byla ověřována na datovém podsouboru z University of Sydney, kde byl v rámci zkoušky spolu s dotazníkem CEQ administrován také dotazník Approaches to Studying Inventory (ASI; Entwistle, Hanley, \& Hounsell, 1979), měřící přístupy studentů k učení. Vzájemné korelace mezi škálami CEQ a ASI potvrdily výše zmíněné předpokládané vztahy mezi vnímáním výuky studenty a jejich přístupy k učení (Ramsden, 1991).

Korelace položky celkové spokojenosti s výukou se všemi škálami CEQ byly statisticky signifikantní. Nebyly tak vysoké, aby bylo možné jednotlivé škály s celkovou spokojeností s výukou ztotožnit, ale jejich hodnoty podle autora podpořily validitu nástroje (s DV 0,60; s JCS 0,47; s PZ 0,21; s PH 0,40 a s DN 0,40). Celková spokojenost studenta s výukou je konstruktem závislým na řadě podmínek, z nichž CEQ zjišt'uje pouze některé (Ramsden, 1991).

Třetí způsob testování kriteriální validity dotazníku využil sebehodnocení výuky učiteli prováděná na stejných škálách jako hodnocení výuky studenty. Výsledky těchto sebeposouzení ukázaly stejný trend jako příslušná studentská hodnocení včetně rozdílů mezi oblastmi a akademickými jednotkami a zároveň odpovídaly vzorci, který již dříve objevil Marsh (1987), a sice že vyučující měli tendenci hodnotit svou výuku příznivěji nežli jejich studenti (Ramsden, 1991).

V rámci národní zkoušky byl dále testován efekt možnosti výběru studijní oblasti pro hodnocení a efekt průměrování hodnot při posuzování více členů učitelského sboru najednou. Ani jeden z nich se nepotvrdil jako činitel negativně ovlivňující validitu dat.

Mezi vnímáním výuky studenty různých oborů byly identifikovány významné rozdíly na škálách Dobrá výuka, Jasné cíle a Přiměřená zátěž, které Ramsden 
(1991) interpretoval dvěma způsoby: v prvé řadě si povšiml, že určité obory jsou v rámci země typicky vyučovány hưře nežli jiné. Další zjištění se opírá o Biglanovou klasifikaci vyučovacích domén (1973), která předpokládá existenci odlišných pedagogických kultur, v rámci kterých se jednotlivé obory liší nejenom zvyklostmi ve vyučovacích praktikách, ale také například poměrem počtu studentů na jednoho učitele. Bez ohledu na jevy, které tyto rozdíly způsobily, z tohoto zjištění jasně vyplynulo, že porovnání institucí je smysluplné pouze $\mathrm{v}$ rámci stejných oborů.

Na základě těchto výsledků byl dotazník CEQ označen za spolehlivý a validní nástroj k měření globální studentské zkušenosti (Ramsden, 1991) a bylo rozhodnuto o jeho administraci na národní úrovni v rámci Graduate Destination Survey, každoročního šetření čerstvých absolventů všech australských univerzit a vysokých škol. První proběhlo v roce 1993 na absolventech z roku 1992 a získalo více než 50000 využitelných odpovědí od absolventů z 30 vysokoškolských institucí. Následně realizovaná šetření pokrývala všechny australské univerzity a typicky získávala data od více než 80000 absolventů, což představovalo 60\% návratnost ze všech obeslaných absolventů (Ainley \& Long, 1995; Long \& Hillman, 2000).

V dalších letech se dotazník CEQ stal východiskem nejrůznějších modifikací, úprav a vzniku nových verzí, jejichž využití překročilo původní účel, úrovně i kontexty. Analýza těchto výsledků ve vztahu k potenciální přínosnosti CEQ pro podmínky českých vysokých škol bude předmětem následující části.

\section{Dotazník CEQ: analýza zkušeností získaných z dostupných empirických studií}

Ve vazbě na hledání nástrojů pro evaluaci vysokoškolské výuky v podmínkách českého školství jsme provedli analýzu dostupných empirických a přehledových studií reflektujících zkušenosti s dotazníkem CEQ. Popis postupu a přehled výsledků jsou obsahem této části.

\subsection{Metoda}

Analýza probíhala $\mathrm{v}$ několika krocích. $\mathrm{V}$ první fázi byly vyhledávány empirické a přehledové studie využívající nebo popisující dotazník CEQ. Přehled se opírá o soubor příspěvků vypracovaných v letech 1989-2018, rok 1989 koresponduje s rokem vzniku první verze CEQ. Rešerše byla provedena 
v databázích WOS, EBSCO a ERIC zadáním klíčových slov „Course Experience Questionnaire“. Dále jsme také nahlédli do časopisu Review of Educational Research. Celkově bylo tímto postupem nalezeno 138 odlišných výsledků. Dalších 23 studií bylo získáno metodou sněhové koule z odkazů analyzovaných studií.

V následujícím kroku byly analyzovány abstrakty všech těchto výsledků, přičemž do výběru byly zařazeny pouze výstupy, které zároveň splňovaly následující podmínky: (1) pouze práce zaměřené na vývoj, validaci nebo adaptaci dotazníku CEQ nebo dotazníku, jehož je dotazník CEQ součástí (jako např. SCEQ nebo USE); (2) pouze práce obsahující přesně popsané metodologické postupy související s vývojem či úpravami dotazníku; (3) pouze práce založené na empirickém výzkumu nebo jeho přehledu; (4) pouze práce zaměřené na oblast vysokého školství; (5) pouze práce s přesně popsaným zkoumaným souborem a způsobem jeho výběru ( $v$ př́padě empirických studií); (6) pouze práce publikované v anglickém jazyce. Důvodem poslední podmínky byla jazyková přístupnost pro autory s tím, že vzhledem k původu vzniku instrumentu lze předpokládat nejhojnější využívání a publikování v anglickém jazyce.

Po vyloučení studií, které ověřovaly využitelnost nástroje mimo terciární vzdělávání, příspěvků prezentujících tutéž empirickou studii v různých periodicích, příspěvků typu předmluv ke sborníkům, recenzí a dvou příspěvků psaných ve španělském jazyce dosahoval výsledný počet analyzovaných studií 103. Následně byly všechny studie detailně pročítány a jejich cíle, metody a zjištění zaznamenávány do sumarizující tabulky.

V dalším kroku byly s využitím postupů tematické analýzy záznamy v tabulce kódovány z hlediska aspektů dotazníku, na něž se zaměřují. Postupným porovnáváním jsme dospěli ke čtyřem kategoriím vyjadřujícím aspekty dotazníku, z hlediska kterých jsme zjištění z analyzovaných studií hodnotili a diskutovali: (1) dimenzionalita dotazníku; (2) psychometrické vlastnosti; (3) účely použití a úrovně měření; (4) práce s výsledky.

\subsection{Výsledky}

Tabulka 2 shrnuje četnost zastoupení jednotlivých kategorií témat v námi analyzovaném souboru studií a odkazuje na některé $\mathrm{z}$ nich. Vzhledem $\mathrm{k}$ tomu, že mnohé ze studií přispívají k více kategoriím, součet jednotlivých kategorií neodpovídá celkovému počtu analyzovaných příspěvků. Každému 
z identifikovaných aspektů dotazníku je věnována jedna z podkapitol, v nichž jsou shrnuta hlavní zjištění a následně diskutovány možné př́nosy i omezení CEQ pro potenciálního českého uživatele.

\section{Tabulka 2}

Počty analyzovaných studií v jednotlivých kategoriích

\begin{tabular}{|c|c|c|c|}
\hline & $\begin{array}{l}\text { Tematická } \\
\text { kategorie }\end{array}$ & $\begin{array}{l}\text { Počet } \\
\text { studií }\end{array}$ & Př́íklady studií \\
\hline 1 & $\begin{array}{l}\text { Dimenzionalita } \\
\text { dotazníku }\end{array}$ & 72 & $\begin{array}{l}\text { např. Feldman, 1978; Ramsden \& Entwistle, 1981; Entwistle } \\
\text { \& Ramsden, 1983; Elphinstone, 1990; Entwistle \& Tait, 1990; } \\
\text { Linke, 1991; Ramsden, 1991; Ainley \& Long, 1994; Richardson, } \\
\text { 1994; Ainley \& Long, 1995; Wilson, Lizzio, \& Ramsden, 1997; } \\
\text { Long \& Hillman, 2000; McInnis et al., 2001; Lizzio, Wilson, } \\
\text { \& Simons, 2002; Griffin et al., 2003; Richardson, 2005a; Diseth } \\
\text { et al., 2006; Webster et al., 2009; Chan \& Chan, 2010; Ning } \\
\text { \& Downing, 2010; Barattucci \& Zuffo, 2012; Fryer et al., 2012; } \\
\text { Jansen et al., 2013; Yin, Lu \& Wang, 2014; Yin \& Wang, 2015 }\end{array}$ \\
\hline 2 & $\begin{array}{l}\text { Psychometrické } \\
\text { vlastnosti }\end{array}$ & 96 & $\begin{array}{l}\text { např. Richardson, 1994; Eley, 2001; Lizzio et al., 2002; Byrne } \\
\text { \&; Espeland \& Indrehus, 2003; Flood, 2003; Richardson, 2003; } \\
\text { Karagiannopoulou \& Christodoulides, 2005; Richardson et al., } \\
\text { 2005; Diseth et al., 2006; Diseth, 2007; Surrige, 2007; Struyven } \\
\text { et al., 2008; Webster et al., 2009; Yorke, 2009; Chan \& Chan, } \\
\text { 2010; Ning \& Downing, 2010; Ashby, Richardson, \& Woodley, } \\
\text { 2011; Carrol, 2011; Barattucci \& Zuffo, 2012; Fryer et al., 2012; } \\
\text { Richardson, 2012; Jansen et al., 2013; Yin et al., 2014; Yin } \\
\text { \& Wang, } 2015\end{array}$ \\
\hline 3 & $\begin{array}{l}\text { Účely použití } \\
\text { a úrovně měření }\end{array}$ & 22 & $\begin{array}{l}\text { např. Ramsden, 1991; Ainley \& Long, 1994; Richardson, 1994; } \\
\text { Ainley \& Long, 1995; Wilson, Lizzio, \& Ramsden, 1997; Long } \\
\text { \& Hillman, 2000; Eley, 2001; McInnis et al., 2001; Griffin et al., } \\
\text { 2003; Richardson, 2005b; Surrige, 2007; Yorke, 2009; Ashby } \\
\text { et al., 2011; Carroll, 2011; Richardson, 2012; } \\
\text { např. Broomfield \& Bligh, 1998; Barrie, 2001; DEST, 2001; } \\
\text { McInnis et al., 2001; Smith et al., 2001; Lawless \& Richardson, } \\
\text { 2002; Lizzio, Wilson, \& Simons, 2002; Griffin et al., 2003; } \\
\text { Prosser \& Barrie; 2003; Richardson \& Price, 2003; Barrie } \\
\text { \& Prosser, 2004; Ginns \& Barrie, 2004; Barrie, Ginns, \& Prosser, } \\
\text { 2005; Nijhuis, Segers, \& Gijselaers, 2005; Richardson, 2005b; } \\
\text { Ginns, Prosser, \& Barrie, 2007; Patrick et al., 2008; Struyven, } \\
\text { Dochy, \& Janssens, 2008; Ginns \& Ellis, 2009 }\end{array}$ \\
\hline 4 & Práce s výsledky & 9 & $\begin{array}{l}\text { DEST, 1994; McInnis, Griffin, James \& Coates, 2001; Barrie } \\
\text { \& Prosser, 2002; Lizzio, Wilson, \& Simons, 2002; Ginns \& Barrie, } \\
\text { 2004; Barrie, Ginns, \& Prosser, 2005; Barrie \& Ginns, 2007; } \\
\text { Ginns, Prosser, \& Barrie, 2007; Talukdar, Aspland, \& Datta, } 2013\end{array}$ \\
\hline
\end{tabular}




\subsubsection{Dimenzionalita dotazníku}

\section{Teoretický základ dimenzí}

Dimenzionalita je jedna z klíčových vlastností dotazníků, která je základem jejich obsahové validity a pro uživatele dotazníku jistoty, že dotazník měří to, co měřit má. Na straně potenciálních uživatelů je v případě CEQ jednoznačnou výhodou, že jeho dimenze jsou odvozené z teorie (SLT) a v minulosti byly mnohokrát empiricky ověřovány $\mathrm{v}$ různých studijních kontextech ve vztahu k ní. Velká část námi analyzovaných studií této kategorie testovala vztahy škál CEQ se studentovými přístupy k učení, podstatně menší počet příspěvků se zabýval vztahy dotazníku s výsledky učení.

Př́stupy $\mathrm{k}$ učení byly $\mathrm{v}$ rámci těchto studií měřeny několika dotazníky odvozenými od dvou základních instrumentů z 80. let - SPQ: Study Process Questionnaire (Biggs, 1987) a ASI: Approaches to Study Inventory (Entwistle et al., 1979). Jejich novější verze, které byly v těchto studiích použity, zahrnovaly R-SPQ-2F, revidovanou dvoufaktorovou verzi SPQ (Bigg, Kember, \& Leung, 2001), ASSIST: Approaches and Study Skills Inventory for Students (Tait, Entwistle, \& McCune 1997) a RASI: Revised Approaches to Study Inventory (Entwistle, Tait, \& McCune, 2000). Metodou analýzy těchto vztahů byla korelační analýza (např. Broomfield \& Bligh, 1998; Byrne \& Flood, 2003), regresní analýza (např. Lawless \& Richardson, 2002; Jelfs \& Richardson, 2010) nebo strukturální modelování (např. Diseth et al., 2006; Diseth, 2007; Ning \& Downing, 2010; Yin, Lu, \& Wang, 2014; Ratanaolarn, 2016; Sun \& Richardson, 2016; Hongbiao \& Zheng, 2017).

Strukturálního modelování bylo shodně využíváno především k testování teoretického modelu, zahrnujícího ověřování kauzálních vztahů mezi studentovou zkušeností, jeho př́istupy k učení a studijními výsledky. Například Lizzio, Wilsonová a Simons (2002) testovali kauzální model vztahů na obrovském, transdisciplinárním souboru více než 5000 australských studentů. Kategorie vstupních (presage) proměnných byla tvořena dvěma osobními (gender a studijní prospěch z předchozího vzdělávání) a dvěma environmentálními proměnnými (vnímaná kvalita výuky a vnímaná studijní zátěž měřené škálami CEQ). Procesní kategorie modelu (process) byla zastoupena studentovými přístupy $\mathrm{k}$ učení měřenými dotazníkem ASI (Entwistle et al., 1979). Výslednou dimenzi modelu (product) tvořily tři proměnné: prospěch, vyjádřený váženým aritmetickým průměrem (GPA), položkou celkové 
spokojenosti s výukou, která je pravidelnou součástí CEQ a skóry na škále Generické dovednosti. Výsledkem analýz bylo zjištění, že studentovy percepce výuky měly vliv jak na tvrdé (prospěch), tak i na měkké (spokojenost a klíčové dovednosti) studijní výsledky, a to jak prrímý, tak i zprostředkovaný, skrze př́ístupy k učení. Studentovo vnímání aktuálního studijního prostředí bylo silnějším prediktorem studijních výsledků nežli prospěch v jeho předchozím vzdělávání. U studentů několika fakult byla shodně nejsilnějším prediktorem GPA škála Dobrá výuka. Mnohem méně studií se zaměřilo na testování vztahu škál CEQ se studijními výsledky a tento vztah se v porovnání se vztahem k přístupům k učení ukázal jako problematičtější. Diseth s kolegy (2006) například na vzorku 475 začínajících norských studentů psychologie testovali předpokládanou kauzální souvislost mezi vnímanou zkušeností studentů (měřenou dotazníkem CEQ), jejich přístupy k učení (měřenými dotazníkem ASSIST) a známkou ze zkoušení a zajímali se rovněž o relativní důležitost těchto dvou sad proměnných jako prediktorů akademických výsledků u studentů psychologie. Metodou strukturálního modelování kauzálních vztahů mezi těmito proměnnými podobně jako Lizzio a kol. (2002) dospěli autoři k závěru o kauzálním vztahu mezi CEQ a studijními přístupy, avšak jako prediktor akademických výsledků nebo mediačních efektů se CEQ potvrdit nepodařilo. Zjištění byla autory interpretována jako důsledek nedostatečné zkušenosti začínajících studentů s hodnoticími praktikami, avšak je třeba vzít také $v$ úvahu, že studie proběhla v jiném kulturním prostředí (norské školství), $v$ němž se hodnoticí praktiky nemusí shodovat s postupy využívanými v Austrálii. Lze si např́íklad snadno představit studijní prostředí, která z různých důvodů v rámci hodnocení nedostatečně diferencují mezi výsledky dosaženými na základě povrchnějších (pamětních) postupů a výsledky dosaženými využíváním hloubkových studijních strategií. V těchto př́ípadech dotazník CEQ vystavený na teorii SLT nemusí být prediktorem studijních výsledků.

Dotazník CEQ se výrazně odlišuje od mnoha dalších evaluačních nástrojů využívaných ve vysokém školství, z nichž mnohé mají nevyjasněnou teoretickou strukturu (Spooren, Brockx, \& Mortlemans, 2013). Z dalších teoretických konceptů, od nichž se však autoři studií využívající CEQ distancují, jsou koncept angažovanosti (Kuh, 2009) a koncept hodnocení studentovy spokojenosti (Harvey \& Kamvounias, 2008). 
Koncept angažovanosti je využíván $\mathrm{v}$ rámci národního šetření $\mathrm{v}$ USA (The National Survey of Student Engagement; NSSE) a staví na předpokladu, že kvalita učebních výsledků je determinována způsobem, jakým se studenti angažují ve vysokoškolském vzdělávání. Jde o behaviorálně orientovaný konstrukt popisující studentovo chování a institucionální praktiky vztažené ke studentově spokojenosti a výkonu operacionalizovaném jako čas trávený na úlohách, sociální a akademická integrace a vyučovací praktiky (Australian Council for Educational Research, 2010b). Vztahy mezi studijní zkušeností (vyjádřenou CEQ) a angažovaností v učení (konceptualizovanou studentovou angažovaností) se snažili hledat čínští výzkumníci Hongbiao a Zheng (2017) na vzorku 882 hongkongských studentů. S využitím metody SEM identifikovali pozitivní vztahy mezi studentovou angažovaností a škálami Jasné cíle a standardy, Přiměřená zátěž a Generické dovednosti. Oproti tomu Přiměřené hodnocení mělo na studentovu angažovanost dvojí efekt a škály Dobrá výuka a Důraz na nezávislost měly dokonce nežádoucí efekt na studentovo zapojení se do učení. Koncept angažovanosti však sklidil kritiku pro rozporuplný teoretický základ a nedostatečné rozlišování mezi faktory ovlivňujícími studentovo zapojení a okamžitými i dlouhodobějšími důsledky studentovy angažovanosti (Kahu, 2013).

Autoři některých námi analyzovaných studií varují zejména před konceptem studentovy spokojenosti, který je podle Richardsona (2005b) základem nezanedbatelné části evaluačních dotazníků používaných v anglofonních zemích. Nástroje mají povahu hodnocení úrovně spokojenosti studenta, která je uváděna do souvislosti s teorií zákazníka. Ta předpokládá, že rozdíl mezi očekáváním a vnímáním reality zákazníkem determinuje úroveň jeho spokojenosti s kvalitou poskytovaných služeb (Harvey \& Kamvounias, 2008). Tato perspektiva však byla jako teoretické východisko pro hodnocení kvality vysokoškolské výuky zpochybňována s odůvodněním, že spokojenost není homogenním a dostatečně probádaným konstruktem. Výzkumná zjištění kritiku podporují a ukazují, že jde o koncept silně ovlivnitelný řadou kontextuálních faktorů bez vazby na kvalitu vyučování (Wiers-Jenssen et al., 2002, cit. podle Richardson, 2005b). Jako argument proti ztotožňování studentovy spokojenosti s kvalitou výuky použil Richardson (2005b) rovněž odkaz na výzkumné výsledky psychologů zabývajících se intelektuálním vývojem studentů (Perry, 1970; Baxter Magolda, 1992), jejichž zjištění potvrzují, že intelektuální vývoj je spojen s určitým diskomfortem. 


\section{Modifikace dotazníkových dimenzí}

Pro účely národního testování byly dimenze dotazníku CEQ několikrát výrazně modifikovány. První úprava byla provedena velmi záhy (1992) a spočívala v připojení šestipoložkové škály Generické dovednosti (GD). Generické dovednosti postihují „míru, do které vysoké školství přispívá ke zvyšování dovedností relevantních k zaměstnatelnosti“ (Ainley \& Long, 1994, s. XII). Škála obsahovala šest nových položek pokrývajících dovednosti řešení problémů, analytické dovednosti, dovednosti týmové spolupráce, komunikace a plánování práce (např. „Studium mi pomohlo rozvinout schopnost plánovat svou práci“). S výjimkou jediné položky celkové spokojenosti s výukou představují GD jedinou škálu zaměřující se na vnímání výsledků, přičemž ostatní škály CEQ operacionalizují subjektivní vnímání studijního kontextu.

Vynecháním škály Důraz na nezávislost a několika nejméně korelujících položek z dalších škál z CEQ36 vznikla zkrácená, 23položková verze CEQ, od roku 1993 využívaná v rámci GCCA v australském vysokém školství (Ainley \& Long, 1994). Krácení mělo kompenzovat připojení škály Generické dovednosti a předejít potížím s prř́liš dlouhým dotazníkem.

Naopak k rozšíření dotazníku došlo znovu v roce 2001, kdy McInnis a kol. (2001) zareagovali na kritiku stávajícího CEQ, že jeho dobré psychometrické vlastnosti jdou na vrub postižení širšího okruhu studentské zkušenosti (Yorke, 1995, cit. podle Wilson, Lizzio, \& Ramsden, 1997) a v rámci nově utvořeného rozšíření dotazníku CEQ vyvinuli pět nových škál sycených celkem 25 položkami: (1) Podpora studenta konceptualizuje př́istup a spokojenost se zařízeními a širší podporou studijních výsledků (napřr „Relevantní studijní zdroje byly dostupné, když bylo třeba"); (2) Studijní zdroje vyjadřují vhodnost a efektivitu zdrojů informací a materiálů k předmětu (napřr. „Studijní materiály byly jasné a výstižné"); (3) Učební komunita měří míru, do jaké příslušnost k univerzitě přispívá k učení (např. „V průběhu předmětu byly využívány myšlenky a návrhy studentů“); (4) Kvality absolventa slučují existující položky generických dovedností s kvalitami asociovanými s celoživotním učením (např̀ „Předmět rozvinul mou důvěru v objevování nových myšlenek") a (5) škála Intelektuální motivace konceptualizuje míru inspirace a motivace, kterou studenti asociují se studijní zkušeností (např. „Předmět stimuloval můj zájem o tuto oblast studia"). Autoři konstatovali, že skóry studentů na nových škálách korelují se skóry pěti škál původně 23položkového CEQ, a prohlásili, že zahrnutí nových škál neovlivňuje odpovědi studentů 
na škály původní (Griffin et al., 2003). Nové škály byly v rámci australského národního šetření (GCCA) od roku 2002 nabízeny jako dobrovolně volitelné součásti (Richardson, 2005b). Proti tendenci k rozšiřování dotazníku CEQ o př́liš mnoho neformálních aspektů studentské zkušenosti se objevila varování (Koder, 1999; Richardson, 2005b). Richardson (2005b) kritizoval závěry a interpretace McInnise a kol. (2001) a poukazoval, že faktorové analýze součtových skórů na všech škálách dominovaly nové škály na úkor těch původních, což může znamenat vnímání takto rozšířené verze dotazníku CEQ jako dominantně zaměřené na neformální aspekty vysokoškolského vzdělávání (zdroje a podpůrné systémy) spíše než na formální aspekty kurikula, které obvykle charakterizují kvalitu výuky. Oproti rozšiřování dotazníku CEQ argumentoval rovněž autor originální verze (Ramsden, 1991) poukázáním na zjištění, že širší aspekty studentské zkušenosti, jako je např́íklad kvalita vybavenosti institucí nebo poskytování dalších služeb, se ukázaly být mnohem slabším prediktorem celkové studentské spokojenosti. Přehled všech výše zmíněných validovaných verzí dotazníku shrnuje tabulka 3.

Tabulka 3

Základní údaje k jednotlivým verzím dotazníku CEQ

\begin{tabular}{|c|c|c|c|}
\hline Verze & Autor & Škály/položky & Okolnosti vzniku \\
\hline CEQ30 & $\begin{array}{l}\text { Ramsden, } \\
1991\end{array}$ & $\begin{array}{l}5 \text { škál: DV/8 pol., JCS/5, PZ/5, } \\
\text { PH/6, DN/6 }\end{array}$ & $\begin{array}{l}\text { Indikátor akademického výkonu } \\
\text { v oblasti měření globální } \\
\text { studijní zkušenosti absolventů } \\
\text { (Australské národní šetření } \\
\text { absolventů - GCCA). }\end{array}$ \\
\hline CEQ36 & $\begin{array}{l}\text { DEET, } 1992 \\
\text { Ainley \& } \\
\text { Long, } 1994\end{array}$ & $\begin{array}{l}\text { CEQ30 + škála Generické } \\
\text { dovednosti/6 }\end{array}$ & $\begin{array}{l}\text { Odpověd' na obavy stran } \\
\text { uplatnitelnosti absolventů. }\end{array}$ \\
\hline CEQ23 & $\begin{array}{l}\text { Ainley \& } \\
\text { Long, } 1994\end{array}$ & $\begin{array}{l}\text { Vynechání škály DN z CEQ36 a } \\
\text { několika problematických položek; } \\
5 \text { škál: DV/6, JCS/4, PZ/4, PH/3, } \\
\text { GD/6 }\end{array}$ & $\begin{array}{l}\text { Kompenzace připojení škály } \\
\text { Generických dovedností; verze } \\
\text { od roku } 1993 \text { využívaná v rámci } \\
\text { GCCA v australském vysokém } \\
\text { školství. }\end{array}$ \\
\hline CEQ50 & $\begin{array}{l}\text { McInnis et } \\
\text { al., } 2001\end{array}$ & $\begin{array}{l}\text { Přidání } 5 \text { nových subškál } \\
\text { a } 25 \text { položek ke zkrácené } \\
\text { CEQ23 + } 2 \text { pol.; Podpora } \\
\text { studenta/5, Studijní zdroje/5, } \\
\text { Studijní komunita/5, Kvality } \\
\text { absolventa/6, Intelektuální } \\
\text { motivace/4 }\end{array}$ & $\begin{array}{l}\text { Rozšíření studentské zkušenosti } \\
\text { o další dimenze. }\end{array}$ \\
\hline
\end{tabular}




\section{Shrnutí}

Dimenze dotazníku CEQ jsou teoreticky podloženy a empiricky ověřeny, což poskytuje dotazníku smysluplnou a odůvodněnou strukturu a přispívá k jeho dobrým psychometrickým vlastnostem. Za významnou úpravu je možné považovat připojení škály Generické dovednosti, která operacionalizuje hodnocení výuky z hlediska vnímaných výsledků oproti ostatním škálám, které jsou zaměřeny na percepci výukového kontextu. I přes řadu modifikací a existenci více verzí však nebyl od roku 2001 dotazník aktualizován z hlediska nových teoretických zjištění. $V$ rámci námi analyzovaných studií byl zaznamenán pouze jeden příspěvek k rozšířením teorie studentova učení, který byl vztahován $\mathrm{k}$ dotazníku CEQ. Konkrétně se jednalo o návrh na integraci teoretického rámce odcizení (alienace) do SLT (Barnhardt \& Ginns, 2014), který však do dimenzionality dotazníku dosud nezasáhl. S ohledem na růst heterogenity studentské populace i rozvoj porozumění procesům učení by syntéza stávajících teoretických př́íspěvků a zohlednění role některých aktuálně více probádaných faktorů (emoce, motivace, metakognice) působících $\mathrm{v}$ obecné rovině nebo přítomných pouze ve specifických studijních kontextech a u konkrétních populací studentů mohla být posunem směrem k holističtějšímu a teoreticky lépe zdůvodněnému modelu a dotazníku.Existující pokusy o rozšíření originálních škál zároveň naznačují, že při rozšiřování dotazníku o nové škály je třeba postupovat obezřetně a uvážlivě a při jejich využívání vycházet $\mathrm{z}$ cílů evaluace, charakteristik, specifik hodnoceného kontextu. Podstatnou podmínkou adekvátního využívání a interpretace výsledků jakékoli verze je vždy dobrá obeznámenost uživatele dotazníku s jeho teoretickými východisky.

\subsubsection{Psychometrické vlastnosti CEQ}

\section{Adaptace dotazníku v jiných kontextech a kulturách}

Dobré psychometrické vlastnosti dotazníku pro hodnocení zkušenosti studentů $\mathrm{v}$ různých zemích, kulturách i vzdělávacích kontextech byly v průběhu již téměř třiceti let jeho existence opakovaně potvrzeny. I přesto se $\mathrm{v}$ námi analyzovaných studiích ukázalo, že tyto kvality mohou být při použití dotazníku v jiných vzdělávacích kontextech, at' už vlivem překladu nebo odlišným způsobem reprezentování konstruktu, ohroženy a že adaptace dotazníku pro používání v těchto kontextech se mnohdy neobejde bez určitých modifikací (viz tabulka 4). 
Studie, které využily CEQ pro identifikování studijní zkušenosti v dalších zemích, zpravidla nejprve testují validitu a reliabilitu dotazníku pro danou populaci a následně prezentují výsledky identifikované studijní zkušenosti ve vztahu ke specifickým charakteristikám studentů nebo vzdělávacího prostředí. 


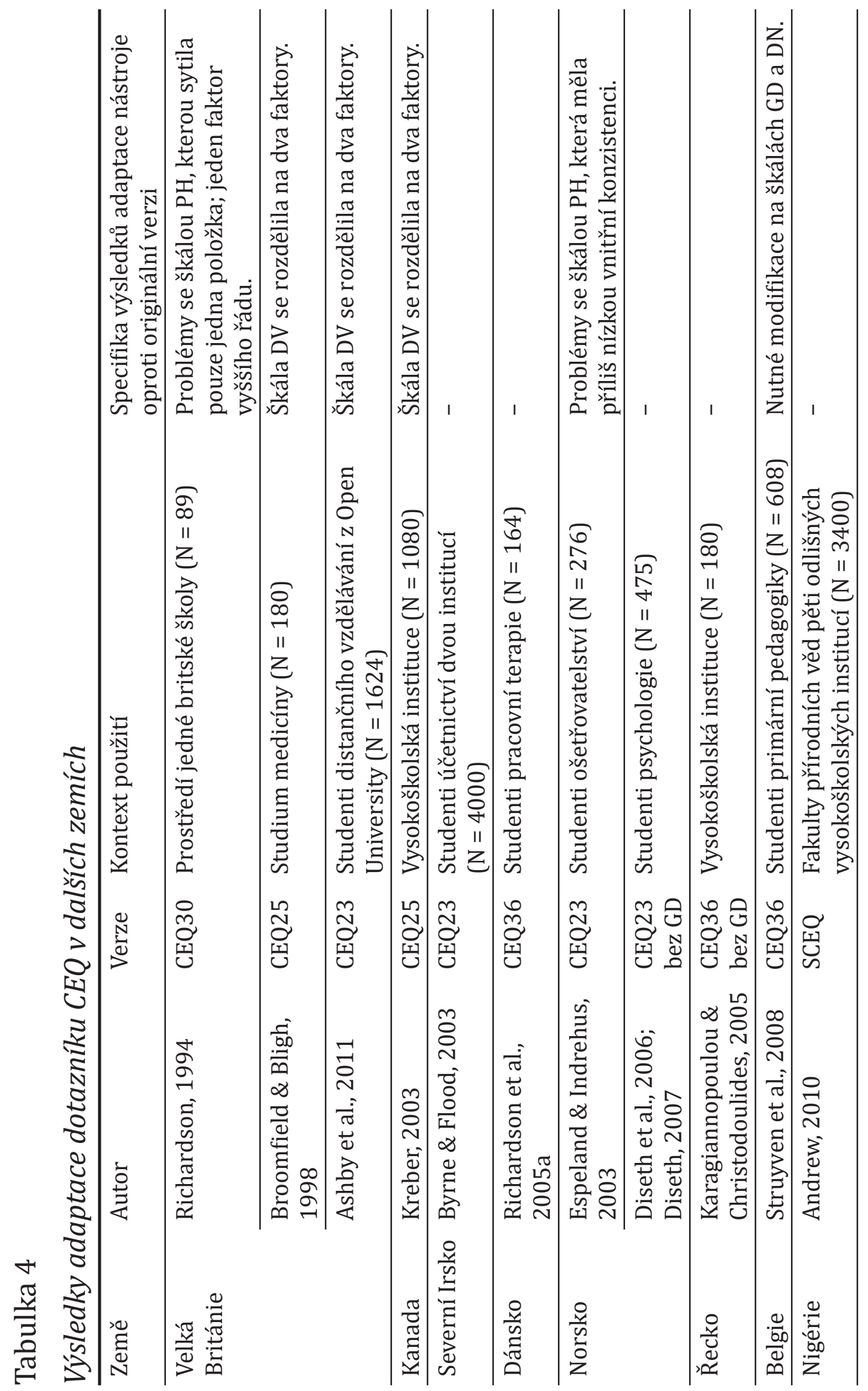




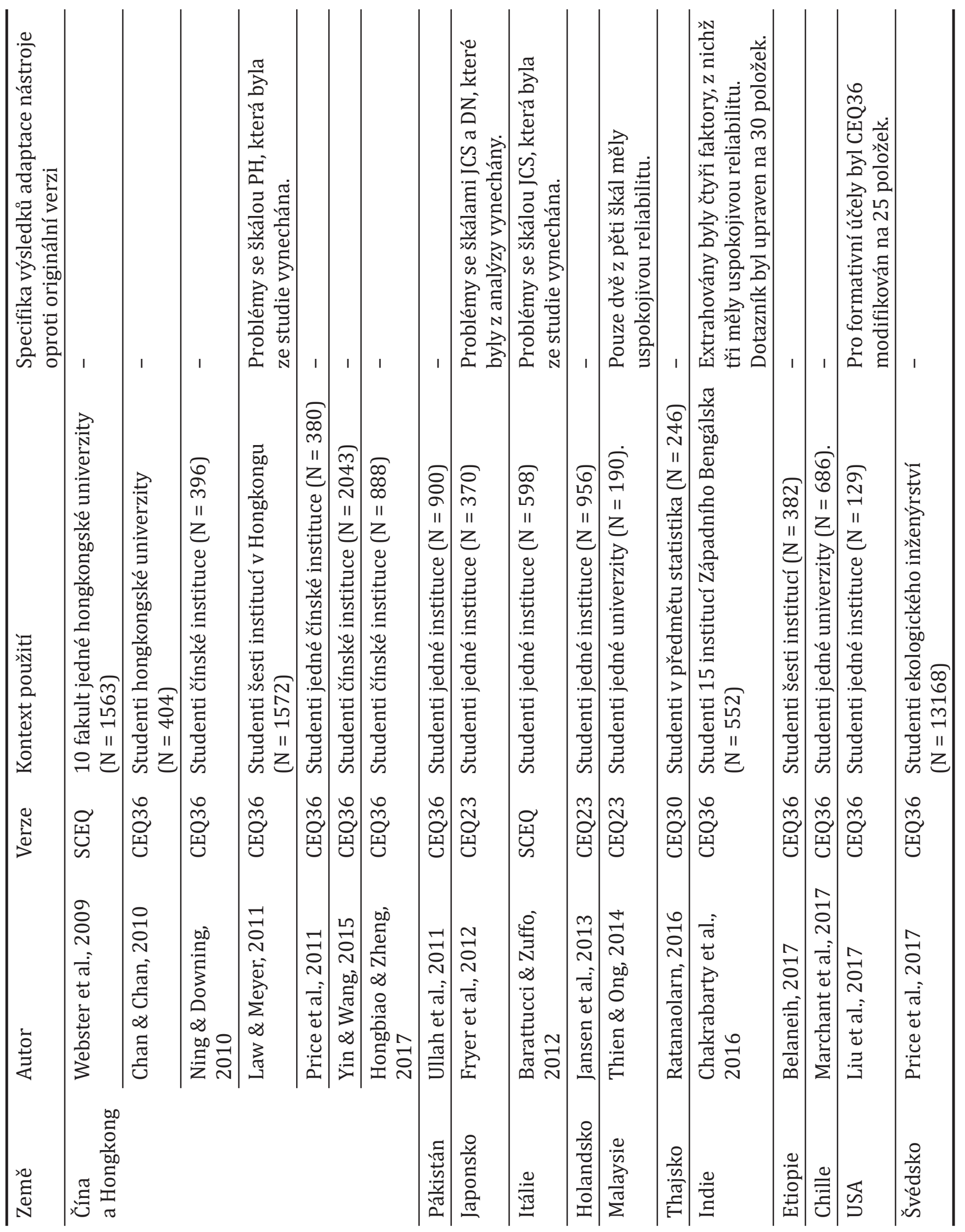


Měření studijní zkušenosti v rámci jednotlivých studií této kategorie je realizováno na různých úrovních - od globální zkušenosti absolventů na národní úrovni až po úroveň studentské zkušenosti z jediného předmětu. S výjimkou Austrálie, Velké Británie a Holandska, odkud pocházejí doklady o použití na národní úrovni, a Číny, kde byly testovány velké soubory studentů, byl dotazník CEQ ve většině zemí uvedených v tabulce 4 použit obvykle na menším souboru studentů jedné instituce.

Ověřování psychometrických charakteristik v nových kulturních podmínkách probíhalo bud'to po vzoru originální Ramsdenovy studie (1991) s využitím exploratorní faktorové analýzy metodou hlavních komponent s šikmou rotací1 ${ }^{1}$ pro testování dimenzí dotazníku a výpočtu koeficientu Cronbachova alfa pro testování vnitřní konzistence jednotlivých škál nebo s použitím konfirmační faktorové analýzy, případně obou postupů.

Někteří autoři testovali také faktor druhého řádu, aby ověřili, zda je možné poskytnout informaci o globální hodnotě vnímané kvality výuky, avšak s rozporuplnými výsledky. Zatímco Richardson (1994) a Byrneová s Floodovou (2003) dospěly k jednomu faktoru vyššího řádu, Wilsonová s kolegy (1997) doložili lepší ukazatele shody u dvoufaktorového řešení, v němž první faktor zahrnoval škály DV, JCS, PH a GD a faktor druhý byl tvořen pouze škálou PZ. V žádné další z námi analyzovaných studií se otázce celkového součtového skóru autoři již nevěnují a shodně pracují se skóry jednotlivých škál.

Nejčastěji využívanými verzemi jsou kratší CEQ23 a CEQ36, která se díky zahrnutí škály Důraz na nezávislost stala populární zejména v Číně, kde se jejím prostřednictvím podařilo poukázat na autonomii studenta jako na opomíjenou kvalitu s významnými dopady na studijní chování i výsledky (Yin, Lu, \& Wang, 2014). Jiní autoři naopak nevyužili žádnou z výše uvedených verzí celou, ale škály volili jednotlivě s ohledem na charakter konkrétního kontextu a evaluační či výzkumné záměry. Diseth a kol. (2006) např́klad pro zachycení studijní zkušenosti v jednom předmětu vynechali škálu GD se zdůvodněním, že rozvíjení generických dovedností nebylo cílem hodnoceného předmětu. Podobně pro neaplikovatelnost v řeckém kontextu vyloučili škálu GD z CEQ Karagiannopoulou a Christodoulides (2005), a naopak využili navíc některých škál z dotazníku CPQ (Ramsden \& Entwistle, 1981).

1 Výjimkou v našem datovém souboru byla studie z čínského prostředí, v níž byla použita rotace Varimax (Webster et al., 2009). 
Větší polovina studií z dalších zemí potvrdila originální faktorovou strukturu použité dotazníkové verze, nezanedbatelná část studií však zmiňovala nutnost úprav. Nejčastěji je uváděno rozdělení škály Dobré výuky do dvou faktorů interpretovatelných jako dobrá práce učitele/tutora a dobré studijní materiály (Broomfield \& Bligh, 1988; Lawless \& Richardson, 2002; Kreber, 2003; Ashby et al., 2011). Jiné problémy s replikací faktorové struktury originální verze uvedli Law a Meyer (2011), Barattucci a Zuffo (2012), Fryer a kol. (2012) a Thien a Ong (2014). Specifika těchto problémů stručně shrnuje tabulka 4.

\section{Formáty prezentování položek a způsoby odpovídání}

Vedle obsahu škál a položek se někteří autoři zaměřili na potenciální ohrožení validity a reliability získaných odpovědí vlivem různých forem prezentace položek, možností nabízených odpovědí nebo způsobů sběru dat.

Eley (2001) publikoval dvě studie, v nichž se zabýval vlivem způsobu prezentace položek v dotazníku CEQ na vzorce odpovědí. V první studii porovnával tři formáty prezentace dotazníkových položek verze CEQ23. První verze měla formát standardního dotazníku využívaného v rámci CCGA, druhá verze změnila položky v souladu s behaviorálními observačními škálami tak, že z původní verze odstranila časové výrazy, syntaktické odkazy na „kurz/ předmět" a respondent odpovídal na pětibodové škále kontinua souhlasímnesouhlasím. Třetí verze využila formát dimenzionálních ratingových škál, u nichž byl respondent žádán o hodnocení na pětibodové škále od „velmi dobrý“ až po „velmi slabý“. Autor zjistil, že druhá a třetí verze měly lepší vnitřní konzistenci i faktorovou strukturu v porovnání s verzí první a ukázaly potenciál pro lepší rozlišování mezi akademickými jednotkami, což vedlo k naději, že alternativní formáty mohou pomoci zlepšit psychometrické vlastnosti CEQ. Přesto však reliabilita i validita standardní verze měly přijatelné hodnoty. Druhá publikovaná studie byla kvalitativní $(\mathrm{N}=45)$ a mapovala rozdíly $\mathrm{v}$ rozhodovacích procesech studentů $\mathrm{v}$ prủběhu odpovídání na tři výše popsané testované formáty dotazníku. Její výsledky byly ve vztahu k výsledkům předchozí studie rozporuplné - studenti nefavorizovali žádnou ze tři testovaných verzí. Dalším významným nálezem bylo zjištění, že studenti se při odpovídání na dotazníkové položky nedokáží vyvarovat vzpomínek na konkrétní osoby a že jejich hodnocení se týká vzpomínek na konkrétní osoby, extrémní situace a intenzívně prožívané vztahy (Eley, 2001). 
Surridgeová (2007) se věnovala otázce negativního vlivu administrace dotazníku CEQ po telefonu. V rámci národního šetření studentů v Anglii a Walesu (National Student Survey, dále jen NSS) objevila, že hodnocení respondentů NSS dotazovaných telefonicky byla statisticky významně příznivější v porovnání s hodnocením respondentů, kteří hodnotili formou tužka-papír nebo online dotazníkem. Toto zjištění přičítala větší rychlosti procesu vnímání a odpovídání na položky, které znemožnilo vybavení všech potřebných zkušeností. Jako další možný důvod uvedla sklon k souhlasu jako důsledek uspokojivého chování.

K podobným důsledkům telefonického odpovídání absolventů na CEQ v australském prostředí dospěl Carroll (2011). Telefonicky administrovaný dotazník má pozitivní efekt na zvyšování podílu celkových odpovědí u respondentů, avšak objevují se tendence k významně příznivějšímu hodnocení. Autor svou studii uzavírá poukázáním na nutnost průběhu telefonického administrování podle standardizovaného vzoru.

Yorke (2009) revidoval větší množství studií zabývajících se vlivem způsobů prezentování položek na zkreslené vnímání položky. S oporou o kognitivní teorii odpovídání na položky, která považuje vnímání položky za klíčový aspekt odpovědi (Krosnick, 1999; Tourangeau, Rips, \& Rasinski, 2000, cit. podle Yorke, 2009), testoval několik konkrétních způsobů prezentace položek a možností odpovědí ve vztahu k datům, která generují. Ohrožení validity dat související se způsobem prezentování položek spočívá z perspektivy kognitivních teorií v narušení průběhu odpovídání na položky, které standardně zahrnuje několik stadií kognitivních operací. Podle některých autorů může docházet $\mathrm{k}$ přeskočení i dvou fází a k volbě odpovědi, která se zdá být adekvátní, ale není přesná (Yorke, 2009). Způsob prezentování položek a možností odpovědí může také respondenty povzbuzovat k určitým zkreslujícím stylům odpovídání, které zahrnují různé tendence, např́klad sklon souhlasit s obsahově protichůdnými položkami, sklon odpovídat na dotazník v souladu s vyzněním prvních položek (primární efekt), sklon dávat průměrné, nebo naopak extrémní odpovědi. Ve své studii Yorke (2009) dospěl k závěrům, že i přes možnou př́tomnost různých sklonů respondentů nehraje pořadí ani způsob prezentování položek v př́ípadě dotazníku CEQ významnou roli ve vztahu ke zkreslení dat. Zároveň upozornil na jiné ohrožení validity výsledků, které vychází z vlivu možných zájmů absolventů. Je-li výsledek národního šetření podkladem pro rankingová hodnocení, která jsou zprávou o prestižnosti konkrétních institucí, pak se lze například obávat možnosti záměrného 
zkreslení hodnocení za účelem konstruování obrazu o prestiži vlastního vzdělávání.

Také Richardson (2012) se zabýval otázkou, do jaké míry jsou data ze studentských šetření o vnímané kvalitě výuky artefaktem způsobů, jakými studenti odpovídají na dotazníky. Testoval, do jaké míry je vztah mezi dvěma jevy v rámci určitého teoretického modelu kontaminován sklony studentů k určitému způsobu odpovídání, konkrétně sklonem k souhlasu a k extrémním odpovědím. Zjistil, že odpovědi studentů jsou z velké části založeny na obsahu jednotlivých položek a relativně neovlivněné rozptylem ve sklonu k souhlasným odpovědím. Oproti tomu odhalení obdobných sklonů odpovědí u dotazníku CEQ i dotazníku měřícího př́ístupy k učení vedlo Richardsona (2012) k závěru, že sklony k určitému způsobu odpovídání mohou být částečně odpovědné za vztahy mezi studentovými hodnoceními dosaženými různými instrumenty, ovšem jejich podíl na těchto vztazích je malý.

Ashbyová s kolegy (2011) při použití dotazníku CEQ v kontextu distančního vzdělávání v Anglii, Walesu a Severním Irsku zjistili, že určité položky se pro studenty s touto studijní zkušeností ukázaly jako nevhodné (škály Osobní rozvoj a Učební zdroje). Při př́ipravě dotazníku byla proto mezi odpovědi přidána možnost odpovědi „nepoužitelné“ (not aplicable). I přesto se objevily anomálie ve výsledcích z roku 2005, které svědčí o různém chápání této možnosti odpovědi.

Huybers (2017) testoval metodu třídění položek na nejvíce a nejméně výstižné (best-worst scaling) jako alternativní způsob odpovídaní na dotazník, který umožňuje výrazněji rozlišovat mezi jednotlivými dotazníkovými položkami z hlediska toho, jak jsou pro studenty relevantní. Studie realizovaná na souboru 263 holandských studentů testovala položky ze dvou dotazníkových škál: Dobrá výuka a Generické dovednosti. Výsledky ukázaly, že pro tuto skupinu studentů byly generické dovednosti mnohem relevantnější v porovnání s dobrou výukou.

\section{Shrnutí}

Přestože četné údaje o adaptacích CEQ v jiných státech a kulturách vyznívají optimisticky, studie z odlišných kulturních a vzdělávacích prostředí vyzývají $\mathrm{k}$ obezřetnosti a k nutnosti věnovat dostatečnou pozornost kvalitnímu překladu a testování konstruktové validity dotazníku v novém studijním prostředí. Při přípravě evaluačního nástroje je možné se poučit z množství studií 
zaměřených na způsoby prezentování položek a rovněž zvážit optimální způsob sběru dat. Přri nedostatku času nebo soustředění pozornosti na položky může podle těchto zjištění docházet k nedostatečnému kognitivnímu zpracování a jeho následkem k neadekvátnímu odpovídání. Rovněž sociální desirabilita je faktor, se kterým je třeba při plánování způsobu sběru dat počítat.

\subsection{3 Účely použití a úrovně měření}

V rámci námi analyzovaných studií jsme zaznamenali využití dotazníku CEQ pro tři různé účely, kterým zpravidla odpovídala úroveň, na jaké studenti svou studijní zkušenost hodnotili - za účelem sumativního hodnocení, za účelem formativního hodnocení a jako výzkumnou proměnnou.

První skupina studií prezentuje použití CEQ v rámci účelů, pro něž vznikla, a sice pro sumativní hodnocení realizovaná na úrovni celostátního hodnocení globální studijní zkušenosti absolventů, př́ípadně globální studijní zkušenosti studentů z jednoho ročníku. $V$ rámci tohoto přístupu jsou škály CEQ používány jako indikátory pedagogického výkonu institucí a slouží např́íklad pro rankingová srovnání porovnatelných předmětových oblastí vysokoškolských institucionálních jednotek (Ramsden, 1991). Tato hodnocení jsou jednak podkladem pro řízení vzdělávací politiky a přidělování finančních zdrojů, ale zároveň jsou využívána různými médii ke konstruování žebříčků univerzit sloužících budoucím studentům pro rozhodování o volbě univerzity.

Poprvé byl CEQ jako součást každoročního národního šetření australských absolventů Graduate Destination Survey (GDS) použit v roce 1993 a od té doby je dodnes v různých modifikacích jeho každoročním prvkem (Talukdar, Aspland, \& Datta, 2013).

Měření globální studijní zkušenosti bylo použito také za účelem formativního sebehodnocení institucí. V reakci na zjištění, že prvotní způsob používání CEQ v rámci šetření absolventů v Austrálii, na Novém Zélandě a v mnoha státech USA poskytuje zpětnovazební data (na jejichž základě navíc není možné spolehlivě usuzovat na to, kde např́klad nastaly zdroje problémů a jak jim do budoucna předejít) od absolventů s několikaletým zpožděním, se začaly vysokoškolské instituce zajímat o možnosti, jak získávat data aktuální. Na úrovni studijního oboru si mnoho australských vysokoškolských institucí adaptovalo dotazník CEQ pro evaluaci studenty, a vznikl tak nástroj sbírající data o aktuální globální studentské zkušenosti v jednom ročníku příslušného studijního oboru (např. Trigwell \& Ashwin, 2003). Dotazník SCEQ (Student 
Course Experience Questionnaire) podstoupil statistické testování, které potvrdilo jeho reliabilitu a validitu (Barrie, Ginns, \& Prosser, 2005; Ginns, Prosser, \& Barrie, 2007). Svou strukturou se s původní verzí shodoval v pěti ze šesti škál (Dobrá výuka, Jasné cíle a standardy, Přiměřená zátěž, Přiměřené hodnocení a Generické dovednosti). Nově připojenou škálou byla 6položková Studijní komunita vyjadřující míru, do jaké studenti vnímají, že ročník studia rozvíjí atributy dovedností stanovené konkrétní institucí (např. „Moje studium rozvíjí dovednost zkoumání a dotazování") (Ginns, Prosser, \& Barrie, 2007). Ne všechny vysokoškolské instituce v Austrálii, na Novém Zélandě a v USA však SCEQ k autoevaluacím využívají, byt' je jejich nespornou výhodou teoretická shoda indikátorů umožňující využívat výsledky získané na různých úrovních a na zpětnou vazbu získanou SCEQ rychleji reagovat.

Ještě méně institucí využilo indikátorů CEQ k tvorbě nástroje měřícího studijní zkušenost na úrovni jednotlivých předmětů. ${ }^{2}$ Výjimkou je např́íklad University of Sydney, kde vznikla verze odvozená od SLT a CEQ, Unit of Study Evaluation (USE). Má charakter velmi stručného dotazníku, jehož položky byly tvořeny definujícími, tj. nejsilněji korelujícími položkami na čtyřech škálách dotazníku CEQ: Dobrá výuka, Jasné cíle a standardy, Přiměřená zátěž a Přiměřené hodnocení (Ginns \& Barrie, 2004). Dotazník neobsahuje žádné položky ze škály Generické dovednosti, ale výbor každého fakultního oboru má možnost vytvořit vlastní položky vystihující dovednosti, které by měl konkrétní předmět rozvíjet. Také u této verze byly výzkumně potvrzeny dobré psychometrické kvality (Ginns \& Barrie, 2004).

Její autoři se zároveň zabývali otázkou, zdali je možné data získaná dotazníky na nižších úrovních měření (tj. USE a SCEQ) agregovat na úrovně vyšší, konkrétně zda je možné vytvořit soubor dat o studijním programu sloučením dat pořízených z hodnocení jednotlivých předmětů (Barrie \& Ginns, 2007). Pro oprávněnost počítání průměrného skóru studijních oborů nebo oddělení byla zjištována tzv. inter-rater reliabilita (Ginns \& Barrie, 2004) porovnávající rozptyl na položkách instrumentu pozorovaný v odpovědích respondentů s předpokládanou variancí na základě rovnoměrně rozložené chyby (Chan, 1998; Lindell, 2001, cit podle Ginns \& Barrie, 2004).

Oba nástroje na nižších úrovních měření (USE a SCEQ) v kombinaci s použitím CEQ v rámci národního šetření absolventů poskytují celkový obraz o pedagogickém výkonu dané instituce, oboru i jednotlivých učitelů, a rozšiřují

2 Byt' mnohé z nich využily některých částí teorie SLT (Barrie \& Ginns, 2007). 
tak charakter získané informace o tom, jak si instituce v rámci jednotlivých oborů vede $\mathrm{v}$ porovnání $\mathrm{s}$ ostatními, o aktuální zpětnou vazbu jednotlivým oddělením i vyučujícím, což umožňuje rychleji a cíleně reagovat ve směru úsilí o zkvalitňování studijní zkušenosti (Ginns \& Barrie, 2004). Přehled všech výše prezentovaných úrovní měření a účelů využívání dotazníku CEQ a dotazníků od něho odvozených shrnuje tabulka 5.

Tabulka 5

Účely využívání dotazníku CEQ a jeho modifikací

\begin{tabular}{|c|c|c|c|c|}
\hline Verze & Autor & Škály/položky & Účel použití & Úroveň měření \\
\hline CEQ30 & $\begin{array}{l}\text { Ramsden, } \\
1991\end{array}$ & $\begin{array}{l}5 \text { škál: DV/8 pol., } \\
\text { JCS/5, PZ/5, PH/6, } \\
\text { DN/6 }\end{array}$ & $\begin{array}{l}\text { Indikátor akademického } \\
\text { výkonu instituce jako podklad } \\
\text { pro řízení vzdělávací politiky } \\
\text { a rozdělování finančních } \\
\text { zdrojů nebo indikátor změny } \\
\text { po pedagogické intervenci } \\
\text { v rámci jednoho nebo } \\
\text { několika předmětů. } \\
\text { Kdo využívá: Australské } \\
\text { národní šetření absolventů } \\
\text { - GCCA; vysokoškolští } \\
\text { pedagogové a výzkumníci. }\end{array}$ & $\begin{array}{l}\text { Globální studijní } \\
\text { zkušenost } \\
\text { absolventů. }\end{array}$ \\
\hline SCEQ & $\begin{array}{l}\text { Trigwell } \\
\text { \& Ashwin, } \\
2003 ; \\
\text { Ginns., } \\
\text { Prosser, } \\
\text { \& Barrie, } \\
2007\end{array}$ & $\begin{array}{l}6 \text { škál/29 položek: } \\
\text { DV/6, JCS/4, } \\
\mathrm{PZ} / 4, \mathrm{PH} / 3, \mathrm{GD} / 6 \text {, } \\
\mathrm{SK}^{*} / 6 . \\
\text { (*SK= studijní } \\
\text { komunita) }\end{array}$ & $\begin{array}{l}\text { Indikátor kvality výuky } \\
\text { v rámci studijních oborů } \\
\text { v průběhu jednoho roku pro } \\
\text { potřeby vlastního rozvoje } \\
\text { instituce. } \\
\text { Kdo využívá: } \\
\text { Jednotlivé instituce pro } \\
\text { institucionální autoevaluaci. }\end{array}$ & $\begin{array}{l}\text { Globální studijní } \\
\text { zkušenost } \\
\text { studenta právě } \\
\text { dostudovaného } \\
\text { ročníku. }\end{array}$ \\
\hline USE & $\begin{array}{l}\text { Ginns } \\
\text { \& Barrie, } \\
2004\end{array}$ & $\begin{array}{l}4 \text { škály tvořené } \\
\text { definující } \\
\text { položkou SCEQ } \\
\text { ze škál: DV, JCS, } \\
\text { PZ, PH. GD jsou } \\
\text { nahrazeny aspekty } \\
\text { specifickými } \\
\text { pro konkrétní } \\
\text { předmět. }\end{array}$ & $\begin{array}{l}\text { Indikátor kvality výuky } \\
\text { pedagoga pro potřeby jeho } \\
\text { vlastního rozvoje. } \\
\text { Kdo využívá: } \\
\text { Jednotliví pedagogové pro } \\
\text { vlastní autoevaluaci. }\end{array}$ & $\begin{array}{l}\text { Globální } \\
\text { i konkrétní } \\
\text { zkušenost } \\
\text { studentů } \\
\text { na úrovni jednoho } \\
\text { předmětu/ } \\
\text { vyučujícího. }\end{array}$ \\
\hline
\end{tabular}

V neposlední řadě byl dotazník CEQ v námi analyzovaných studiích používán $\mathrm{k}$ výzkumným účelům. Přestože se zde jedná o úroveň hodnocení jednoho 
předmětu či pedagoga, autoři obvykle využili plnou verzi CEQ (zpravidla CEQ30 nebo její zkrácenou verzi CEQ23), resp. SCEQ.

Zjištování vnímané kvality výuky na této úrovni má nejčastěji souvislost s ověřováním efektů implementovaných pedagogických inovací, jejichž přehled shrnuje tabulka 6 . Všechny studie ověřující efektivitu konkrétních vyučovacích strategií nebo metod se zároveň zabývaly vztahy mezi konstruktem studijní zkušenost / vnímaná kvalita výuky (operacionalizovaná škálami dotazníku CEQ) a studijní chování (operacionalizované jako přístupy k učení a měřené jedním z několika již zmíněných dotazníků - SPQ R-SPQ-2F, ASI, ASSIST a RASI). Metodou analýzy těchto vztahů byla kanonická korelační analýza nebo strukturální modelování.

\section{Tabulka 6}

Přehled analyzovaných empirických studií využivající CEQ $k$ výzkumným účelům

\begin{tabular}{|c|c|c|c|}
\hline Autor studie & $\begin{array}{l}\text { Účel použití dotazníku } \\
\text { CEQ }\end{array}$ & Instituce, země & Zjištění \\
\hline $\begin{array}{l}\text { Lyon \& Hendry, } \\
2002\end{array}$ & $\begin{array}{l}\text { Zavádění problémové } \\
\text { výuky do předmětů } \\
\text { vyšších ročníků studia } \\
\text { medicíny. }\end{array}$ & $\begin{array}{l}\text { University of } \\
\text { Sydney, Austrálie }\end{array}$ & $\begin{array}{l}\text { Studenti nového programu } \\
\text { hodnotili výuku př́znivěji } \\
\text { v porovnání se starým } \\
\text { programem. To neplatilo pro } \\
\text { škály Jasnost cílů a Přiměřená } \\
\text { zátěž. Určité položky CEQ } \\
\text { nereflektují vzdělávací } \\
\text { filozofii vyučovacích procesů } \\
\text { v problémově zaměřených } \\
\text { programech. }\end{array}$ \\
\hline $\begin{array}{l}\text { Steele, West, } \\
\& \text { Simeon, } 2003\end{array}$ & $\begin{array}{l}\text { Modifikace dotazníku } \\
\text { CEQ25 v prostředí } \\
\text { medicínské fakulty pro } \\
\text { hodnocení inovativních } \\
\text { programů. }\end{array}$ & $\begin{array}{l}\text { Faculty of Medical } \\
\text { Sciences at } \\
\text { St. Augustine, } \\
\text { Trinidad \& Tobago }\end{array}$ & $\begin{array}{l}\text { CEQ30 je spolehlivý nástroj } \\
\text { pro hodnocení kurzu } \\
\text { v dovednostech komunikace } \\
\text { v medicíně a podporuje } \\
\text { reflexi výuky a designu kurzu. }\end{array}$ \\
\hline $\begin{array}{l}\text { Athiyaman, } \\
2001\end{array}$ & $\begin{array}{l}\text { Hodnocením } \\
\text { subjektivní důležitosti } \\
\text { různých druhů } \\
\text { dovedností a atributů } \\
\text { v rámci př́ípravy } \\
\text { na různá povolání } \\
\text { a míry, do níž byly tyto } \\
\text { dovednosti v průběhu } \\
\text { studia rozvíjeny. }\end{array}$ & $\begin{array}{l}\text { Bakalářské } \\
\text { studium obchodu, } \\
\text { Austrálie }\end{array}$ & $\begin{array}{l}\text { Dovednosti požadované } \\
\text { potenciálními zaměstnavateli } \\
\text { studentů nekorespondují } \\
\text { s těmi, které jsou na } \\
\text { základě šetření studentů } \\
\text { hodnoceny jako rozvíjené } \\
\text { vysokoškolskou výukou. }\end{array}$ \\
\hline
\end{tabular}




\begin{tabular}{|c|c|c|c|}
\hline Autor studie & $\begin{array}{l}\text { Účel použití dotazníku } \\
\text { CEQ }\end{array}$ & Instituce, země & Zjištění \\
\hline $\begin{array}{l}\text { Price, } \\
\text { Richardson, } \\
\text { \& Jelfs, } 2007\end{array}$ & $\begin{array}{l}\text { Porovnání CEQ } \\
\text { v distančním učení } \\
\text { při tutorské podpoře } \\
\text { poskytované } \\
\text { limitovaným } \\
\text { osobním kontaktem } \\
\text { a poskytované online. }\end{array}$ & $\begin{array}{l}\text { Distanční studium, } \\
\text { Spojené Království }\end{array}$ & $\begin{array}{l}\text { Tutoring je vnímán nejenom } \\
\text { jako výuka, ale i jako } \\
\text { pastorace. Všechny části } \\
\text { studie potvrdily větší efekt } \\
\text { face-to-face kontaktu. Pro } \\
\text { online vzdělávání je třeba } \\
\text { speciálního tréninku, jak } \\
\text { komunikovat bez účasti } \\
\text { paralingvistických klíčů. }\end{array}$ \\
\hline $\begin{array}{l}\text { Bell, Galilea, } \\
\text { \& Tolouei, } 2010\end{array}$ & $\begin{array}{l}\text { Ověřování vnímání } \\
\text { kvality výuky při } \\
\text { implementaci nových } \\
\text { metod. }\end{array}$ & $\begin{array}{l}\text { Magisterské } \\
\text { studium } \\
\text { stavebního } \\
\text { inženýrství, } \\
\text { Spojené Království }\end{array}$ & $\begin{array}{l}\text { CEQ je možné využít pro } \\
\text { hodnocení efektivity při } \\
\text { zavádění nových metod } \\
\text { (na scénáři založených). }\end{array}$ \\
\hline Sorensen, 2013 & $\begin{array}{l}\text { Ověřování vnímání } \\
\text { kvality výuky při } \\
\text { zavádění e-hodnocení } \\
\text { v oboru chemické } \\
\text { inženýrství. }\end{array}$ & $\begin{array}{l}\text { UCL, } \\
\text { Spojené Království }\end{array}$ & $\begin{array}{l}\text { CEQ byl úspěšně využit jako } \\
\text { nástroj pro vnímání kvality } \\
\text { výuky při pedagogických } \\
\text { inovacích. }\end{array}$ \\
\hline $\begin{array}{l}\text { Harris } \\
\& \text { Kloubec, } \\
2014\end{array}$ & $\begin{array}{l}\text { Adaptace nástroje na } \\
\text { webový dotazník. }\end{array}$ & $\begin{array}{l}\text { Bastyr University, } \\
\text { USA }\end{array}$ & $\begin{array}{l}\text { Validní nástroj. Doporučují } \\
\text { používat CEQ25 pro } \\
\text { formativní hodnocení } \\
\text { ve studijních skupinách. }\end{array}$ \\
\hline $\begin{array}{l}\text { Liu, John, } \\
\text { \& Courtier, } \\
2017\end{array}$ & $\begin{array}{l}\text { Validace CEQ } \\
\text { ve třídách geověd } \\
\text { (STEM). }\end{array}$ & $\begin{array}{l}\text { National } \\
\text { Association } \\
\text { of Geoscience } \\
\text { Teachers, } \\
\text { USA }\end{array}$ & $\begin{array}{l}\text { Adaptace nástroje na webový } \\
\text { dotazník. } \\
\text { Validní nástroj. Doporučují } \\
\text { používat CEQ25 pro } \\
\text { formativní hodnocení } \\
\text { ve třídách. }\end{array}$ \\
\hline
\end{tabular}

\section{Shrnutí}

Studie analyzované v rámci této kategorie výsledků přinesly doklady o možnostech využití CEQ na několika různých úrovních a o jeho př́nosech. Zároveň naznačují, že zpětná vazba pořízená na různých úrovních je určena různým adresátům a je podkladem k přesnější a adresnější odezvě ve směru snah o zlepšení. Globální hodnocení absolventů slouží především k sumativnímu hodnocení institucí, globální hodnocení stávajících studentů je souhrnnou zpětnou vazbou o fungování celých oddělení nebo fakult a hodnocení jednotlivých učitelů/předmětů je zpětnou vazbou pro konkrétního učitele a jeho nadřízeného. Všechny tyto úrovně mají při správném použití potenciál 
poukázat na oblasti vysokoškolské výuky, kde se instituci nebo jednotlivci daří dosahovat dobré kvality (a naopak). Na základě těchto indikátorů je následně možné rozvíjet diskusi a sběr dalších dat k porozumění získaným výsledkům.Shoda $\mathrm{v}$ teoretických indikátorech umožňuje propojit všechny úrovně měření a vytvořit systém zpětné vazby, který je podkladem pro intervence a další činnost mnoha různých aktérů - národních institucí, vedení jednotlivých institucí, vedení jednotlivých oddělení a oborů i jednotlivých pedagogů. Jeho konkrétní možné podoby jsou součástí následujícího oddílu.

\subsubsection{Práce s výsledky}

Konkrétní způsoby práce s výsledky pořízenými evaluací vysokoškolské výuky studenty na různých úrovních jsou obsahem poslední skupiny studií. Zatímco většina námi analyzovaných studií tyto způsoby naznačila pouze na úrovni potenciálních možností (zejména ty, které teprve adaptovaly dotazník pro novou populaci studentů/absolventů), pouze devět námi analyzovaných př́íspěvků se zabývalo konkrétními, již existujícími iniciativami v oblasti implementace výsledků do procesů zkvalitňování výuky (viz tabulka 7). Toto zjištění je tak v souladu s tvrzeními jiných autorů, kteří o mnoho let dříve konstatovali, že úspěšnost vysokoškolských institucí ve sbírání důkazů o výuce je relativně vysoká, ovšem ne tak je tomu v oblasti porozumění tomu, jak, kým a k jakým konkrétním účelům tato data využít (Cannon, 2001; Mullins \& Cannon, 1992, cit. podle Talukdar, Aspland, \& Datta, 2013).

Omezená využitelnost dat $\mathrm{z}$ CEQ získaných $\mathrm{v}$ rámci celonárodních šetření pro formativní účely již byla zmíněna. Ve snaze překonat tato omezení byly vytvořeny dva nové nástroje od CEQ odvozené, SCEQ a USE. Klíčovým problémem, kterým se však námi analyzované studie této kategorie zabývají, je způsob využití dat pořízených těmito nástroji ke zkvalitňování vysokoškolské výuky a studijní zkušenosti v rámci konkrétních institucí.

Talukdar s kolegy (2013) uvádí přehled způsobů využívání CEQ dat z národního šetření z šesti australských vysokoškolských institucí (The University of New South Wales, The University of Melbourne, Swinburne University of Technology, Curtin University of Technology, Queensland University of Technology, The University of Queensland), z něhož vyplývá, že postoje těchto institucí $\mathrm{k}$ př́nosu meziuniverzitního benchmarkingu výsledků CEQ v rámci národního šetření jsou rozporuplné. Zatímco některé instituce je 
vítají, zejména pro možnost identifikovat instituce s nejlepší pedagogickou praxí a sdílet s nimi jejich zkušenosti, jiné o ně nemají zájem, protože věří, že mezi jednotlivými institucemi existují rozdíly, které činí porovnání nemožným. Tyto univerzity využívají data z národního šetření spíše k porovnání se svou interní zpětnou vazbou od studentů.

Oproti tomu Barrie a Ginns (2007) prezentovali př́klad dobré praxe, v rámci které je SCEQ je využíván k porovnávání akademických jednotek University of Sydney s několika dalšími porovnatelnými jednotkami výzkumně orientovaných univerzit - University of Queensland, Monash Univeristy a University of Oxford. Tato vzájemná porovnání (benchmarking relationships) by měla vést $\mathrm{k}$ identifikování nejlepší praxe $\mathrm{v}$ konkrétních oblastech, umožnit sdílení zkušeností a podporovat dialog o různých př́ístupech v rámci stejných jednotek s cílem zkvalitňovat studijní zkušenost na tomto typu univerzit.

Rovněž další autoři (Lizzio, Wilson, \& Simons, 2002; Byrne \& Flood, 2003; Barrie \& Ginns, 2007) upozorňují na využitelnost globálních dat v rámci interních procesů univerzit v indikativním smyslu, který by měl být následován dalšími způsoby hodnocení. Např. Lizzio s kolegy (2002) vyvinuli protokol pro ohniskovou skupinu se studenty ke zkoumání otázek týkajících se škál Přiměřená zátěž a Přiměřené hodnocení, které v konkrétních studijních programech získaly relativně nízká hodnocení. Barrie a Prosser (2002) zdůrazňují důležitost systematické implementace výsledků studentských evaluací do univerzitních systémů zajišt’ujících kvalitu. Podle nich je provázání těchto výsledků s fakultní politikou, manažerskými pokyny, strategickými iniciativami fakulty a vyučovacími praktikami jednotlivých akademiků klíčem k efektivnímu zvyšování kvality vysokoškolské výuky. Podmínky pro možnost úspěšného nastavení těchto aktivit podle autorů umožňuje především silný teoretický základ, který poskytuje koherenci mezi politikami v rámci jedné instituce i např́č několika institucemi (Barrie \& Ginns, 2007).

V jednom z příspěvků Barrie, Ginns a Prosser (2005) seznamují s příklady dobré praxe $\mathrm{v}$ této oblasti $\mathrm{z}$ University of Sydney. Za významný počin autoři považují především zřízení univerzitní jednotky na podporu implementování této politiky do univerzitní politiky a kultury, Institute for Teaching and Learning (ITL). Od roku 1999 ITL sbírá, shromažd'uje a vyhodnocuje studentská hodnocení vysokoškolské výuky na základě šetření stávajících studentů dotazníkem SCEQ a rovněž využívá data pořízená dotazníky USE a CEQ. V reakci na zpětnou vazbu na různých úrovních (individuální učitel, 
oddělení, katedry, obory, fakulty, ročníky) utváří různé strategie a iniciuje aktivity na podporu implementací.

Každoroční skóry SCEQ přispívají ke konstrukci univerzitních indikátorů výkonu, od nichž se vyvíjí financování jednotlivých fakult. Šetření využívající SCEQ bylo rozšířeno o otevřené položky s možností pro studenty doplnit vlastní komentáře, což je zdrojem informací pro akademické rady fakult připravující sebehodnoticí fakultní zprávu založenou na důkazech a následný audit a diskusi procesů a strategií identifikovaných ve zprávě. Důraz je kladen rovněž na využívání dat na nejnižší úrovni (USE); zde mohou posloužit zejména jako podklady pro navrhované fakultní strategie rozvoj kurikula a na úrovni jednotlivých akademických pracovníků jako zdroj informací pro jejich individuální plány. ITL dále využívá data z SCEQ a USE jako východiska pro vytváření řady institucionálních projektů na podporu pracovníků v rozvíjení strategií efektivní výuky a učení, jako je tomu například v případě projektu zaměřujícího se na studijní zkušenost studentů prvního ročníku (The First Year Experience Project).

Implementace zpětnovazebních dat o kvalitě výuky do fungování univerzity má pro univerzitní zaměstnance několik důsledků, $\mathrm{k}$ nimž patří financování, podpora pedagogických kompetencí zaměstnanců a širší reflexe studijní zkušenosti. Skóry SCEQ jsou v rámci jednotlivých fakult východiskem pro jejich financování. Rovněž jednotliví akademičtí pracovníci jsou na základě svých indexů kvality opírajících se částečně o studentská hodnocení finančně odměňováni. ITL dále zř́ídila fond na podporu zlepšení výuky, který se zaměřuje na rozvoj pedagogických kompetencí u akademických pracovníků. Fakulty např́íklad pořádají dny rozvoje výuky a učení, jichž se účastní všichni zaměstnanci. Jednotlivé fakulty jsou povinny pravidelně reflektovat studentskou zpětnou vazbu a odevzdávat vyučovací a učební plány dokumentující jejich strategické odpovědi na otázky identifikované v šetření SCEQ nebo USE jako problematické. Jako doklad o př́nosu těchto praktik Barrie, Ginns a Prosser (2005) prezentovali interní výsledky založené na SCEQ indikující celkové zkvalitnění vysokoškolské výuky, které je možné přičítat výše zmíněným opatřením (Barrie, Ginns, \& Prosser, 2005). 


\section{Tabulka 7}

Přehled analyzovaných empirických studií zabývajících se způsoby práce s daty

\begin{tabular}{|c|c|c|c|}
\hline Autor studie & Instituce, země & $\begin{array}{l}\text { Komentovaný } \\
\text { nástroj / } \\
\text { úroveň měření }\end{array}$ & Obsah zjištění / sdělení \\
\hline DEET, 1994 & Austrálie & CEQ & $\begin{array}{l}\text { Strategie využití výsledků } \\
\text { národního šetření absolventů } \\
\text { v oblasti vnímané kvality výuky } \\
\text { v Austrálii. }\end{array}$ \\
\hline $\begin{array}{l}\text { McInnis, Griffin, } \\
\text { James, \& Coates, } \\
2001\end{array}$ & Austrálie & CEQ & $\begin{array}{l}\text { Možné strategie využití výsledků } \\
\text { z rozšiřujících škál CEQ v rámci } \\
\text { národního šetření absolventů } \\
\text { v oblasti vnímané kvality výuky } \\
\text { v Austrálii. }\end{array}$ \\
\hline $\begin{array}{l}\text { Lizzio, Wilson, } \\
\text { \& Simons, } 2002\end{array}$ & $\begin{array}{l}\text { School of Applied } \\
\text { Psychology a Griffith } \\
\text { University, } \\
\text { Austrálie }\end{array}$ & CEQ & $\begin{array}{l}\text { Návrh protokolů pro focus } \\
\text { groups s cílem jemněji analyzovat } \\
\text { percepci výuky studenty } \\
\text { v oblastech Přiměřená zátěž } \\
\text { a Přiměřené hodnocení. }\end{array}$ \\
\hline $\begin{array}{l}\text { Barrie } \\
\text { \& Prosser, } 2002\end{array}$ & $\begin{array}{l}\text { University of Sydney, } \\
\text { Austrálie }\end{array}$ & SCEQ & $\begin{array}{l}\text { Implementace zpětné vazby } \\
\text { na výuku do institucionálních } \\
\text { systémů jako klíč ke zvyšování } \\
\text { kvality vysokoškolských institucí. }\end{array}$ \\
\hline $\begin{array}{l}\text { Ginns \& Barrie, } \\
2004\end{array}$ & $\begin{array}{l}\text { University of Sydney, } \\
\text { Austrálie }\end{array}$ & USE & $\begin{array}{l}\text { Způsoby použití studentova } \\
\text { hodnocení kvality výuky v rámci } \\
\text { jednoho předmětu/učitele a } \\
\text { podmínky agregování dat na } \\
\text { oborovou úroveň. }\end{array}$ \\
\hline $\begin{array}{l}\text { Barrie, Ginns, } \\
\& \text { Prosser, } 2005\end{array}$ & $\begin{array}{l}\text { University of Sydney, } \\
\text { Austrálie }\end{array}$ & $\begin{array}{l}\text { CEQ, SCEQ } \\
\text { USE / všechny } \\
\text { úrovně měření }\end{array}$ & $\begin{array}{l}\text { Systém hlavních rysů univerzitní } \\
\text { strategie zajišt'ování kvality výuky } \\
\text { opírající se o důkazy poskytnuté } \\
\text { v rámci evaluací výuky studenty } \\
\text { na všech úrovních. }\end{array}$ \\
\hline $\begin{array}{l}\text { Ginns, Prosser, } \\
\text { \& Barrie, } 2007\end{array}$ & $\begin{array}{l}\text { University of Sydney, } \\
\text { Austrálie }\end{array}$ & SCEQ & $\begin{array}{l}\text { Způsoby použití studentova } \\
\text { hodnocení kvality výuky v rámci } \\
\text { jednoho ročníku a podmínky } \\
\text { agregování dat na fakultní úroveň. }\end{array}$ \\
\hline $\begin{array}{l}\text { Barrie \& Ginns, } \\
2007\end{array}$ & $\begin{array}{l}\text { University of Sydney, } \\
\text { Austrálie }\end{array}$ & CEQ, SCEQ & $\begin{array}{l}\text { Spojování dat z národního šetření } \\
\text { kvality výuky s daty na úrovni } \\
\text { fakulty. }\end{array}$ \\
\hline $\begin{array}{l}\text { Talukdar, } \\
\text { Aspland, } \\
\text { \& Datta, } 2013\end{array}$ & $\begin{array}{l}\text { University of } \\
\text { Adelaide,Austrálie }\end{array}$ & CEQ & $\begin{array}{l}\text { Způsoby využívání dat z národního } \\
\text { šetření konkrétními australskými } \\
\text { univerzitami. }\end{array}$ \\
\hline
\end{tabular}




\section{Shrnutí}

Z námi analyzovaných studií je zřejmé, že způsoby využívání výsledků studentských evaluací jsou mnohem méně rozvinuté nežli způsoby jejich získávání, což může souviset např́íklad s citlivostí dat tohoto typu, s nedůvěrou v celý proces a s obavami z možných důsledků. Na druhou stranu, příklady dobré praxe prezentované několika málo studiemi ukazují, že je-li zpětná vazba od studentů implementována do politiky a kultury instituce, může být př́ležitostí nejenom k rozvoji kontroly, ale také k plánování systému péče a odborné podpory pro zaměstnance/pedagogy i studenty, který se opírá o důkazy, sebereflexi a diskusi na různých úrovních.

\section{Diskuse}

Tato část studie se zaměří na syntézu hlavních zjištění o dotazníku CEQ získaných prostřednictvím naší analýzy ve čtyřech sledovaných kategoriích a na diskusi potenciálního př́nosu CEQ pro evaluaci výuky studenty v českém vysokém školství, v rámci které se vyjádříme ke dvěma hlavním otázkám:

01: Která zjištění o dotazníku CEQ hovoří ve prospěch jeho možné využitelnosti $v$ našich podmínkách?

02: Které zkušenosti s CEQ naopak nabádají k obezřetnosti nebo ukazují na potřebu postupovat při zvažování evaluačních procesů odlišně?

Dotazník CEQ patří mezi celosvětově nejrozšiřrenější validované nástroje pro evaluaci výuky studenty ve vysokém školství. Pozornost mnoha zahraničních akademiků a výzkumníků přitáhl především pro svou jednoduchou a teoreticky odůvodněnou strukturu opírající se o teorii studentova učení, která je především $\mathrm{v}$ anglofonních zemích jedním $\mathrm{z}$ dominantních konceptů $\mathrm{v}$ oblasti vysokoškolského vzdělávání (Haggis, 2009).

Teoreticky podložený dotazník je jednou z mála výjimek mezi ostatními dotazníky k evaluaci výuky, které mnohdy postrádají jakýkoli teoretický základ (Richardson, 2005b; Sporen et al., 2013). Dalšími dvěma teoretickými rámci využívanými jako základ pro tvorbu evaluačních dotazníků ve vysokém školství jsou koncept angažovanosti (Kuh, 2009) a koncept hodnocení studentovy spokojenosti (Harvey \& Kamvounias, 2008), oba však byly předmětem kritiky pro teoretickou nejasnost a rozporuplnost (Richardson, 2005b; Kahu, 2013). Varování se objevila zejména před ztotožňováním evaluace kvality 
výuky se zjištováním spokojenosti studenta a poukazovala na skutečnost, že studentova spokojenost je dosud málo probádaný konstrukt ovlivněný řadou faktorů, z nichž jenom některé souvisí s aspekty výuky i s kvalitním učením. Dotazník CEQ oproti tomu staví na faktorech s teoreticky i empiricky dokumentovaným vysoce významným vlivem na kvalitu studentova učení. Teoretický základ je při použití dotazníku výhodou jak pro interpretaci výsledků, tak pro hledání strategií směřujících ke zkvalitnění studijní zkušenosti (Barrie, Ginns, \& Prosser, 2005).

Skutečnost, že indikátory použité v rámci CEQ představují faktory s ověřeným vlivem na procesy a výsledky učení však neznamená, že nemohou existovat žádné další. Teorie studentova učení vznikla v 70. a 80. letech a od té doby se porozumění procesům učení vyvíjí, zejména v souvislosti s vyjasněním některých faktorů, např́iklad emočních (Pekrun \& Linnenbrink-Garcia, 2014), motivačních (Wigfield \& Eccles, 2002), metakognitivních (Veenman, Wolters, \& Afflerchach, 2006) a psychosociálních (Barnhardt \& Ginns, 2014), což se však zatím ve struktuře dotazníku neodrazilo.

V průběhu téměř třicetiletého používání byl CEQ rozšířen o škálu Generické dovednosti, která s výjimkou položky celkové spokojenosti s výukou jako jediná konceptualizuje hodnocení studijních výsledků a stala se široce využívanou a stabilní součástí dotazníku. Oproti tomu ne zcela jednoznačně bylo hodnoceno další rozšíření CEQ o pět škál postihujících širší studijní zkušenost - napřr. Studijní zdroje, Studijní komunita, Podpora studenta (McInnis, Griffin, James, \& Coates, 2001). Zahraniční zkušenosti s CEQ ukázaly, že rozšiřování počtu sledovaných dimenzí může přinášet problémy s nadměrně dlouhým dotazníkem způsobujícím únavu (Richardson, 2005b) a nedostatečné kognitivní zpracování ohrožující validitu získaných odpovědí (Eley, 2001). Na druhou stranu, populace studentů se stává v historickém měřítku více heterogenní, což může mít vliv na potřebu zjištovat v rámci studijní zkušenosti další proměnné. Úpravy dotazníku ve shodě s aktualizovanou teorií jsou žádoucí, ovšem aby neztratil svou původní kvalitu, je třeba je opírat o empirická ověřování.Použitelnost dotazníku CEQ v našich podmínkách je dále podmíněna výsledky testování jeho psychometrických vlastností na populaci českých studentů, které mohou být ohroženy např́iklad odlišnou reprezentací měřeného konstruktu v českém studijním kontextu. Přestože ve větší polovině zahraničních studií se podařilo replikovat originální faktorovou strukturu, v nezanedbatelném počtu byli autoři námi analyzovaných studií nuceni 
učinit některé modifikace, které naznačují, že měřený konstrukt nemusí být v odlišném kulturním prostředí reprezentován zcela shodným způsobem.

Validitu a reliabilitu výsledků je možné ovlivnit také nastavením podmínek pro sběr dat, zvážením formy a způsobu prezentování položek a zajištěním dostatečného podílu navrácených odpovědí, což jsou otázky, k nimž námi analyzované studie přinesly také několik podnětů. Společně tyto studie ukazují, že zajištování podmínek pro získávání validních a spolehlivých dat se neobejde bez implementace těchto procesů do ostatních systémů vysokoškolské instituce. Platnost výsledků může být ohrožena více způsoby, například při dobrovolném vyplnění dotazníku může nastat situace, kdy podíl navrácených odpovědí bude př́liš nízký (Richardson, 2005b, udává např pod $30 \%$ ), aby z něho bylo možné usuzovat na celý soubor studentů. Na druhou stranu, bude-li vyplnění evaluačního dotazníku podmiňovat např́íklad postup studenta do dalšího ročníku, mohou se objevit problémy pramenící ze sociální desirability. Aby bylo možné těmto rizikům předcházet, je třeba se zaměřit na ovlivňování př́stupu celé akademické obce ke studentským evaluacím výuky a zajistit, aby se staly součástí akademické kultury.

K obezřetnosti je potenciální uživatel CEQ dále nabádán zjištěním, že pro studenty je při odpovídání na dotazník obtížné se vyvarovat vzpomínek na konkrétní osoby nebo extrémní zkušenosti (Eley, 2001), což je důležité vzít v úvahu při způsobu prezentace položek i volbě úrovně, na níž bude studijní zkušenost hodnocena. Pokud by mělo také v našich podmínkách platit toto zjištění, pak by hovořilo ve prospěch evaluací na nejnižších úrovních, tj. konkrétního předmětu nebo učitele a případně následně výsledky agregovat na úroveň oddělení, kateder nebo oborů. Také pro oprávněnost využívat data agregovaná z nižších úrovní hodnocení přináší námi analyzované studie inspirativní zkušenosti (Ginns \& Barrie, 2004; Ginns, Prosser, \& Barrie, 2007).

Za potenciálně mimořádně přínosné pro aktuální podmínky českého vysokého školství považujeme příspěvky analyzovaných studií k možným způsobům využívání evaluačních výsledků. Přestože studií zabývajících se aspekty dlouhodobějšího systematického využívání výsledků studentských evaluací je v porovnání s ostatními kategoriemi velmi málo, konkrétní příklady praxe $\mathrm{z}$ australských univerzit podrobněji zasvěcují do více různých možností. Především podrobný popis realizované evaluační praxe z University of Sydney, kde se na základě shody teoretických indikátorů opírajících se o CEQ podařilo propojit evaluační výsledky z více úrovní a vytvořit institucionální 
zpětnovazební systém práce s výsledky, který je podkladem pro další činnost různých aktérů - národních institucí, vedení jednotlivých institucí, vedení jednotlivých oddělení a oborů i jednotlivých pedagogů. Tyto postupy zcela jasně ukazují, že hledání vhodného nástroje k získávání dat o evaluaci výuky je pouze první částí problému, který musí být následován promyšleným způsobem práce s výsledky, jehož součástí je implementace těchto postupů do politiky a kultury instituce a nahlížení na evaluace nejenom jako na systém kontroly, ale rovněž jako na východisko pro zajištování oborné podpory a péče pro zaměstnance/pedagogy i studenty, hlubší sebereflexi a její sdílení na různých úrovních $\mathrm{v}$ rámci institucí.

\section{Závěr}

Cílem příspěvku bylo představit dotazník CEQ na základě analýzy dostupných empirických a přehledových studií prezentovat přehled zkušeností s jeho využíváním a diskutovat jeho potenciální přínos pro použití v podmínkách českého vysokého školství. Celkem 103 analyzovaných studií přispělo ke čtyřem kategoriím výsledků: (1) dimenzionalita dotazníku; (2) psychometrické vlastnosti; (3) účely použití a úrovně měření; (4) práce s výsledky.

Analyzované empirické studie se dominantně zaměřovaly na testování psychometrických vlastností dotazníku, o něco méně studií se zaměřovalo na jeho dimenzionalitu. Podstatně méně výsledků jsme zaznamenali v oblasti úrovní a účelů evaluace a práce s výsledky. Je však nutné připustit, že poslední dvě kategorie výsledků nemusí být nutně součástí žánru „empirické“ nebo „přehledové“ studie, ale bylo by možné je nalézt v různých strategických dokumentech a vnitřních předpisech jednotlivých vysokých škol, k nimž jsme se však námi použitou metodou vyhledávání studií nedostali.

Na základě analýzy dostupných publikovaných zkušeností s dotazníkem CEQ považujeme dotazník CEQ za potenciálně využitelný pro účely studentských evaluací vysokoškolské výuky v podmínkách českého školství, a to zejména pro jeho jasnou a teoreticky podloženou strukturu, která umožňuje jasnou interpretaci a je zároveň východiskem pro rozvíjení strategií pro zkvalitňování vysokoškolské výuky. Oprávněnost platného použití dotazníku je však podmíněna jeho validizací na populaci českých studentů. Spolu s ověřením psychometrických kvalit dotazníku v českém vzdělávacím kontextu stojí potenciální uživatel před několika dalšími rozhodnutími a úvahami. Je třeba zvážit zvolenou úroveň hodnocení a způsob následné práce s výsledky. 
Všechny tyto otázky jsou v rámci námi analyzovaných studií řešeny a při jejich rozhodování v našich podmínkách je možné se o tato zjištění opírat.

\section{Literatura}

Ainley, J., \& Long, M. (1994). The Course Experience survey 1992 graduates. Canberra: Australian Government Publishing Service.

Ainley, J., \& Long, M. (1995). The 1994 Course Experience Questionnaire: A report prepared for the Graduate Careers Council of Australia. Parkville: Graduate Careers Council of Australia.

Andrew, N. P. (2010). Applicability of the student Course Experience Questionnaire (SCEQ) in an African context: The case of Nigerian Universities. Literacy Information and Computer Education Journal (LICEJ), 1(3), 143-150.

Ashby, A., Richardson, J. T. E., \& Woodley, A. (2011). National student feedback surveys in distance education: An investigation at the UK Open University. Open Learning, 26(1), 5-25.

Arthur, L., (2009). From performativity to professionalism: Lecturers' responses to student feedback. Teaching in Higher Education, 14(4), 441-454.

Athiyaman, A., (2001). Graduates' perception about business education: An exploratory research. Journal of Further \& Higher Education, 25(1), 5-19.

Australian Council for Educational Research. (2010b). Doing more for learning: Enhancing engagement and outcomes. Australasian Student Engagement Report. Camberwell: ACER.

Barattucci, M., \& Zuffo, R. G. (2012). Measuring learning environment perceptions: Validation of the italian version of the Approaches to Studying Inventory and the Student Course Experience Questionnaire. TPM: Testing, Psychometrics, Methodology in Applied Psychology, 19(1), 15-33.

Barnhardt, B., \& Ginns, P. (2014). An alienation-based framework for student experience in higher education: New interpretations of past observations in student learning theory. Higher Education, 68(6), 789-805.

Barrie, S. C. (2001). Reflections on student evaluation of teaching: Alignment and congruence in a changing context. Student feedback on teaching: Reflections and projections, 1-16.

Barrie, S., \& Ginns, P. (2007). The linking of institutional performance indicators to improvements in teaching and learning in classrooms. Quality in Higher Education, 13, 275-286.

Barrie, S., Ginns, P., \& Prosser, M. (2005). Early impact and outcomes of an institutionally aligned, student focused learning perspective on teaching quality assurance. Assessment \& Evaluation in Higher Education, 30(6), 641-656.

Barrie, S. C., \& Prosser, M. (2002, záŕí). Aligning research on student learning with institutional policies and practices on evaluation and quality assurance. In 11th ISL Conference, Brussels, 4-6.

Barrie, S. C., \& Prosser, M. (2004). Generic graduate attributes: Citizens for an uncertain future. Higher Education Research and Development, 23(3), 243-246.

Baxter Magolda, M. B. (1992b). Students' epistemologies and academic experiences: Implications for pedagogy. The Review of Higher Education, 15(3), 265-287.

Beaty, E., Dall'Alba, G., \& Marton, F. (1997). The personal experience of learning in higher education: Changing views and enduring perspectives. In P. Sutherland (Ed.), Adult learning: A reader (s. 150-165). London: Kogan Page. 
Belaineh, M. S. (2017). Students' conception of learning environment and their approach to learning and its implication on quality education. Educational Research and Reviews, 12(14), 695-703.

Bell, S., Galilea, P., \& Tolouei, R. (2010). Student experience of a scenario-centred curriculum. European Journal of Engineering Education, 35(3), 235-245.

Biggs, J. B. (1987). Learning Process Questionnaire Manual. Student Approaches to Learning and Studying. Hawthorn: Australian Council for Educational Research Ltd.

Biggs, J. (1989). Approaches to the enhancement of tertiary teaching. Higher Education Research and Development, 8, 7-25.

Biggs, J., Kember, D., \& Leung, D. Y. P. (2001). The revised two-factor study process questionnaire: R-SPQ-2F. British Journal of Educational Psychology, 71, 133-149.

Biglan, A. (1973). The characteristics of subject matter in different academic areas. Journal of Applied Psychology, 57, 195-203.

Broomfield, D., \& Bligh, J. (1998). An evaluation of the short form course experience questionnaire with medical students. Medical Education, 32(4), 367-369.

Byrne, M., \& Flood, B. (2003). Assessing the teaching quality of accounting programmes: An evaluation of the Course Experience Questionnaire. Assessment \& Evaluation in Higher Education, 28(2), 135.

Cameron, L. (2017). How learning designs, teaching methods and activities differ by discipline in Australian universities. Journal of Learning Design, 10(2), 69-84.

Carroll, D. (2011). An analysis of mode effects in the 2010 Course Experience Questionnaire. Journal of Institutional Research, 16(2), 1-12.

Cashin, W. E., \& Perrin, P. B. (1978). IDEA technical report no. 4. Description of IDEA standard form data base. Manhattan: Center for Faculty Evaluation and Development in Higher Education.

Chakrabarty, A. K., Richardson, J. T. E., \& Sen, M. K. (2016). Validating the Course Experience Questionnaire in West Bengal higher secondary education. Studies in Educational Evaluation, 50, 71-78.

Chan, Y. M., \& Chan, C. M. S. (2010). Approach to learning of sub-degree students in Hong Kong. Research in Education, 84(1), 65-78.

DEPARTMENT OF EMPLOYMENT, EDUCATION, AND TRAINING (1994). Diversity and Performance of Australian Universities. Higher Education Series No 22. Canberra: DEET.

Department of Education, Science and Training (DEST). (2001, prosinec). Characteristics and performance indicators of Australian higher education institutions, 2000: Occasional paper series.

Diseth, Å. (2003). Personality and approaches to learning as predictors of academic achievement. European Journal of Personality, 17(2), 14-155.

Diseth, Å., Pallesen, S., Hovland, A., \& Larsen, S. (2006). Course experience, approaches to learning and academic achievement. Education and Training, 48(2/3), 156-169.

Diseth, Å. (2007). Approaches to learning, course experience and examination grade among undergraduate psychology students: testing of mediator effects and construct validity. Studies in Higher Education, 32(3), 373-388.

Eley, M. (2001). The Course Experience Questionnaire: Altering question format and phrasing could improve the CEQ's effectiveness. Higher Education Research and Development, 20(3), 293-312. 
Elphinstone, L. J. (1990). The development of the Course Experience Questionnaire (Unpublished M.Ed. thesis). University of Melbourne.

Entwistle, N. (1989). Approaches to studying and course perceptions: The case of the disappearing relationship. Studies in Higher Education, 14(2), 155-156.

Entwistle, N. J., Hanley, M., \& Hounsell, D. (1979). Identifying distinctive approaches to studying. Higher Education, 8, 365-380.

Entwistle, N. J., McCune, V., \& Tait, H. (1997). The approaches and study skills inventory for students (ASSIST). Edinburgh: Centre for Research on Learning and Instruction, University of Edinburgh.

Entwistle, N. J., \& Ramsden, P. (1983). Understanding student learning. London: Croom Helm.

Entwistle, N. J., \& Tait, H. (1990). Approaches to learning, evaluations of teaching and preferences for contrasting academic environments. Higher Education, 19, 169-194.

Entwistle, N. J., Tait, H., \& McCune, V. (2000). Patterns of response to an approaches to studyinginventory across contrasting groups and contexts. European Journal of Psychology of Education. 15(1), 33-48.

Espeland, V., \& Indrehus, O. (2003). Evaluation of students' satisfaction with nursing education in Norway. Journal of Advanced Nursing, 42(3), 226-236.

Feldman, K. A. (1978). Course characteristics and college students' rations of their teachers and courses: What we know and what we don't. Research in Higher Education, 9, 166-242.

Fryer, L. K., Ginns, P., Walker, R. A., \& Nakao, K. (2012). The adaptation and validation of the CEQ and the R-SPQ-2F to the Japanese tertiary environment. British Journal of Educational Psychology, 82(4), 549-563.

Gaff, J. F., Crombag, H., \& Chang, T. (1976). Faculty cultures and interdisciplinary studies. Journal of Higher Education, 3, 186-201.

Ginns, P., \& Barrie, S. (2004). Reliability of single-item ratings of quality in higher education: A replication. Psychological Reports, 95, 1023-1030.

Ginns, P., \& Ellis, R. A. (2009). Evaluating the quality of e-learning at the degree level in the student experience of blended learning. British Journal of Educational Technology, 40(4), 652-663.

Ginns, P., Prosser, M., \& Barrie, S. (2007). Students' perceptions of teaching quality in higher education: The perspective of currently enrolled students. Studies in Higher Education, 32(5), 603-615.

Gow, L., Balla, J., Kember, D., Stokes, M., et al. (1989). Approaches to study of tertiary students in Hong Kong. Bulletin of the Hong Kong Psychological Society, 22-23, 57-77.

Griffin, P., Coates, H., McInnis, C., \& James, R. (2003). The development of an Extended Course Experience Questionnaire. Quality in Higher Education, 9(3), 259-266.

Haggis, T. (2009). What have we been thinking of? A critical overview of 40 years of student learning research in higher education. Studies in Higher Education, 34(4), 377-390.

Harris, C., \& Kloubec, J. (2014). Assessment of student experience in a problem-based learning course using the Course Experience Questionnaire. Journal of Nutrition Education \& Behavior, 46(4), 315-319.

Harvey, A., \& Kamvounias, P. (2008). Bridging the implementation gap: a teacher-as-learner approach to teaching and learning policy. Higher Education Research and Development, 27(1), 31-41. 
Hongbiao, Y., \& Zheng, K. (2017). Students' course experience and engagement: An attempt to bridge two lines of research on the quality of undergraduate education. Assessment \& Evaluation in Higher Education, 42(7), 1145-1158.

Huybers, T. (2017). Exploring the use of best-worst scaling to elicit course experience questionnaire responses. Assessment \& Evaluation in Higher Education, 42(8), 1306-1318.

Jansen, E., van der Meer, J., \& Fokkens-Bruinsma, M. (2013). Validation and use of the CEQ in The Netherlands. Quality assurance in education: An international perspective, 21(4), 330-343.

Jelfs, A., \& Richardson, J. T. E. (2010). Perceptions of academic quality and approaches to studying among disabled and nondisabled students in distance education. Studies in Higher Education, 35(5), 593-607.

Johnson, T., Ainley, J., \& Long, M. (1996). The 1995 Course Experience Questionnaire: A report prepared for the Graduate Careers Council of Australia. Parkville, Victoria: Graduate Careers Council of Australia.

Kahu, E. R. (2013). Framing student engagement in higher education. Studies in higher education, 38(5), 758-773.

Karagiannopoulou, E., \& Christodoulides, P. (2005). The impact of Greek university students' perceptions of their learning environment on approaches to studying and academic outcomes. International Journal of Educational Research, 43(6), 329-350.

Koder, M. (1999). Summary of symposium proceedings. The Course Experience Questionnaire symposium 1998. Australia: Evaluations and Investigations Programme, Higher Education Division, Department of Education, Training and Youth Affairs.

Kreber, C. (2003). The relationship between students' course perception and their approaches to studying in undergraduate science courses: A Canadian experience. Higher Education Research and Development, 22, 57-75.

Kuh, G. D. (2009). The national survey of student engagement: Conceptual and empirical foundation. New Direction for Institutional Research, 141, 5-20.

Landbeck, R., \& Mugler, F. (1994). Approaches to study and conceptions of learning of students at the USP. Fiji: University of the South Pacific, Centre for the Enhancement of Learning and Teaching.

Law, D., \& Meyer, J. (2011). Relationships between Hong Kong students' perceptions of the learning environment and their learning patterns in post-secondary education. Higher Education, 62(1), 27-47.

Lawless, C. J., \& Richardson, J. T. E. (2002). Approaches to studying and perceptions of academic quality in distance education. Higher Education, 44(2), 257-282.

Lawless, C., \& Richardson, J. T. E. (2004). Monitoring the experiences of graduates in distance education. Studies in Higher Education, 29(3), 353-374.

Linke, R. D. (1991). Report of the Research Group on Performance Indicators in Higher Education. Canberra: Canberra Department of Employment, Education and Training.

Liu, J. C., St. John, K., \& Courtier, A. M. B. (2017). Development and validation of an assessment instrument for course experience in a general education integrated science course. Journal of Geoscience Education, 65(4), 435-454.

Lizzio, A., Wilson, K., \& Simons, R. (2002). University students' perceptions of the learning environment and academic outcomes: Implications for theory and practice. Studies in Higher Education, 27, 27-52. 
Long, M., \& Hillman, K. (2000). Course Experience Questionnaire 1999: a report prepared for the Graduate. Parkville, Victoria: Graduate Careers Council of Australia.

Lyon, P. M., \& Hendry, G. D. (2002). The use of the Course Experience Questionnaire as a monitoring evaluation tool in a problem-based medical programme. Assessment \& Evaluation in Higher Education, 27(4), 339-352.

Marchant, J., González, C., \& Fauré, J. (2017). The impact of a university teaching development programme on student approaches to studying and learning experience: Evidence from Chile. Assessment \& Evaluation in Higher Education, 43(5), 697-709.

Mareš, J., \& Došlá, Š. (2008). Studentské posuzování kvality výuky na celouniverzitní úrovni. Brno: MSD.

Mareš, J., \& Ježek, S. (2013). Externí hodnocení kvality na vysokých školách využívající názory studentů. Pedagogika, 3, 301-327.

Marsh, H. W. (1982). SEEQ: A reliable, valid and useful instrument for collecting students' evaluations of university teaching. British Journal of Educational Psychology, 52, 77-95.

Marsh, H. W. (1987). Students' evaluations of university teaching: Research findings, methodological issues, and directions for future research. International Journal of Educational Research.

Marton, F., \& Saljö, R. (1976). On qualitative differences in learning I - outcome and process. British journal of Educational Psychology, 46, 4-11.

Marton, F., \& Pang, M. F. (2006). On some neccessary conditions of learning. Journal of the Learning Sciences, 15, 193-220.

McInnis, C., Griffin, P., James, R., \& Coates, H. (2001). Development of the Course Experience Questionnaire (CEQ). Canberra: Department of Education, Training and Youth Affairs.

Nijhuis, J. F. H., Segers, M. S. R., \& Gijselaers, W. H. (2005). Influence of redesigning a learning environment on student perceptions and learning strategies. Learning Environments Research, 8, 67-93.

Ning, H. K., \& Downing, K. (2010). Connections between learning experience, study behaviour and academic performance: A longitudinal study. Educational Research, 52(4), 457-468.

Patrick, K., Bedford, A., Romagnano, S., Bedford, M., \& Barber, J. (2008). A discipline-specific factor analysis approach to using student surveys for improvement. Journal of Institutional Research.

Pekrun, R., \& Linnenbrink-Garcia, L. (2014). International handbook of emotions in education. New York: Routledge.

Perry, W. G. (1970). Forms of intellectual and ethical development in the college years: A scheme. New York: Holt, Rinehart \& Winston.

Price, L., Richardson, J. T. E., \& Jelfs, A. (2007). Face-to-face versus online tutoring support in distance education. Studies in Higher Education, 32(1), 1-20.

Price, L., et al. (2011). Approaches to studying and perceptions of the academic environment among university students in China. Asia Pacific Journal of Education, 31(2), 159-175.

Price, L., Svensson, I., Borell, J., \& Richardson, J. T. E. (2017). The role of gender in students' ratings of teaching quality in computer science and environmental engineering. IEEE Transactions on Education, 60(4), 281-287. 
Prosser, M., \& Barrie, S. C. (2003). Using a student-focused learning perspective to align academic development with institutional quality assurance. Towards strategic staff development in higher education, 191-221.

Ramsden, P. (1979). Student learning and perceptions of the academic environment. Higher education, 8(4), 411-427.

Ramsden, P. (1991). A performance indicator of teaching quality in higher education: The Course Experience Questionnaire. Studies in Higher Education, 16(2), 129-151.

Ramsden, P., \& Entwistle, N. J. (1981). Effects of academic departments on students' approaches to studying. British Journal of Educational Psychology, 51, 368-383.

Ramsden, P., Martin, E., \& Bowden, J. (1989). School environmentand sixth from pupils'approaches to learning. British Journal of Educational Psychology, 59, 129-142.

Ratanaolarn, T. (2016). The development of a structural equation model of graduate students' statistics achievement. International Journal of Behavioral Science, 11(2), 153-168.

Richardson, J. T. E. (1994). A British evaluation of the Course Experience Questionnaire. Studies in Higher Education, 19(1), 59.

Richardson, J. T. E. (2003). Approaches to studying and perceptions of academic quality in a short web-based course. British Journal of Educational Technology, 34(4), 433-442.

Richardson, J. T. E. (2005a). Students' perceptions of academic quality and approaches to studying in distance education. British Educational Research Journal, 31(1), 7-27.

Richardson, J. T. E. (2005b). Instruments for obtaining student feedback: A review of the literature. Assessment \& Evaluation in Higher Education, 30(4), 387-415.

Richardson, J. T. E. (2006a). Perceptions of academic quality and approaches to studying among technology students in distance education. European Journal of Engineering Education, 31(4), 421-433.

Richardson, J. T. E. (2006b). Investigating the relationship between variations in students' perceptions of their academic environment and variations in study behavior in distance education. British Journal of Educational Psychology, 76(4), 867-893.

Richardson, J. T. E. (2009a). Face-to-face versus online tutoring support in humanities courses in distance education. Arts and Humanities in Higher Education: An International Journal of Theory, Research and Practice, 8(1), 69-85.

Richardson, J. T. E. (2009b). The role of ethnicity in the attainment and experiences of graduates in distance education. Higher Education, 58(3), 321-338.

Richardson, J. T. E. (2010). Perceived academic quality and approaches to studying in higher education: Evidence from Danish students of occupational therapy. Scandinavian Journal of Educational Research, 54(2), 189-203.

Richardson, J. T. E. (2012). The role of response biases in the relationship between students' perceptions of their courses and their approaches to studying in higher education. British Educational Research Journal, 38(3), 399-418.

Richardson, J. T. E., \& Price, L. (2003). Approaches to studying and perceptions of academic quality in electronically delivered courses. British Journal of Educational Technology, 34(1), 45-56.

Richardson, J. T. E., \& Woodley, A. (2001). Perceptions of academic quality among students with a hearing loss in distance education. Journal of Educational Psychology, 93(3), 563. 
Richardson, J. T. E., Dawson, L., Sadlo, G., Jenkins, V., \& Mcinnes, J. (2007). Perceived academic quality and approaches to studying in the health professions. Medical Teacher, 29(5), 108-116.

Richardson, J. T. E., Gamborg, G., \& Hammerberg, G. (2005). Perceived academic quality and approaches to studying at Danish schools of occupational therapy. Scandinavian Journal of Occupational Therapy, 12(3), 110-117.

Richardson, J. T. E., Long, G. L., \& Woodley, A. (2003). Academic engagement and perceptions of quality in distance education. Open Learning, 18(3), 223-244.

Richardson, J. T. E., Marschark, M., Sarchet, T., \& Sapere, P. (2010). Deaf and hard-of-hearing students' experiences in mainstream and separate postsecondary education. Journal of Deaf Studies and Deaf Education, 15(4), 358-382.

Säljö, R. (1979). Learning about learning. Higher Education, 8, 443-451.

Simpson, P., \& Siguaw, J. (2000). Student evaluations of teaching: An exploratory study of the faculty response. Journal of Marketing Education, 22, 199-213.

Smith, C., Herbert, D., Robinson, W., \& Watt, K. (2001). Quality assurance through a continuous curriculum review (CCR) strategy: Reflections on a pilot project. Assessment \& Evaluation in Higher Education, 26(5), 489-502.

Sorensen, E. (2013). Implementation and student perceptions of e-assessment in a chemical engineering module. European Journal of Engineering Education, 38(2), 172-185.

Spooren, P., Brockx, B., \& Mortlemans, D. (2013). On the validity of student evaluation of teaching: The state of the art. Review of Educational Research, 83(4), 598-642.

Steele, G., West, S., \& Simeon, D. (2003). Using a modified Course Experience Questionnaire (CEQ) to evaluate the innovative teaching of medical communication skills. Education for Health: Change in Learning \& Practice, 16(2), 133.

Struyven, K., Dochy, F., \& Janssens, S. (2008). Students' likes and dislikes regarding studentactivating and lecture-based educational settings: Consequences for students' perceptions of the learning environment, student learning and performance. European Journal of Psychology of Education - EJPE, 23(3), 295-317.

Sun, H., \& Richardson, J. (2011). Perceptions of quality and approaches to studying in higher education: A comparative study of Chinese and British postgraduate students at six British business schools. Higher Education, 63(3), 299-316.

Sun, H., \& Richardson, J. T. E. (2016). Students' perceptions of the academic environment and approaches to studying in British postgraduate business education. Assessment \& Evaluation in Higher Education, 41(3), 384-399.

Surridge, P. (2007). The national student survey 2006: Findings.

Talukdar, J., Aspland, T., \& Datta, P. (2013). Australian higher education and the Course Experience Questionnaire: Insights, implications and recommendations. Australian Universities' Review, 55(1), 27.

Thakur, M., \& Hourigan, C. (2007). International student experience: What it is, what it means and why it matters. Journal of Institutional Research, 13(1), 42-61.

Thien, L. M., \& Ong, M. Y. (2014). The applicability of course experience questionnaire for a Malaysian university context. Quality Assurance in Education: An International Perspective, 24(1), 41-55. 
Trigwell, K., \& Ashwin, P. (2003). Undergraduate students' experience oflearning at the University of Oxford.

Trigwell, K., \& Prosser, M. (1991). Improving the quality of student learning: The influence of learning context and student approaches to learning on learning outcomes. Higher Education, 22, 251-266.

Trigwell, K., \& Prosser, M. (1996). Changing approaches to teaching: A relational perspective. Studies in Higher Education, 21(3), 275-284.

Tucker, B., Jones, S., \& Straker, L. (2008). Online student evaluation improves course experience questionnaire results in a physiotherapy program. Higher Education Research and Development, 27, 281-296.

Ullah, R., Richardson, J. T. E., \& Hafeez, M. (2011). Approaches to studying and perceptions of the academic environment among university students in Pakistan. Compare: A Journal of Comparative \& International Education, 41(1), 113-127.

Van Rossum, E. J., \& Taylor, I. P. (1987, duben). The relationship between conceptions of learning and good teaching: A scheme of cognitive development. Paper presented at the Annual Meeting of the American Educational Research Association, Washington DC, USA.

Vašutová, J. (2002). Strategie výuky ve vysokoškolském vzdělávání. Praha: PedF UK.

Webster, B. J., Chan, W. S. C., Prosser, M. T., \& Watkins, D. A. (2009). Undergraduates' learning experience and learning process: Quantitative evidence from the East. Higher Education, $58(3), 375-386$.

Wigfield, A., \& Eccles, J. S. (2002). The development of competence beliefs, expectancies for success, and achievement values from childhood through adolescence. In Development of achievement motivation (s. 91-120). Academic Press.

Wilson, K. L., Lizzio, A., \& Ramsden, P. (1997). The development, validation and application of the Course Experience Questionnaire. Studies in Higher Education, 22(1), 33.

Yin, H., \& Wang, W. (2015). Assessing and improving the quality of undergraduate teaching in China: the Course Experience Questionnaire. Assessment \& Evaluation in Higher Education, 40(8), 1032-1049.

Yin, H., Lu, G., \& Wang, W. (2014). Unmasking the teaching quality of higher education: Students' course experience and approaches to learning in China. Assessment \& Evaluation in Higher Education, 39(8), 949-970.

Young, S., \& Shaw, D. G. (1999). Profiles of effective college and university teachers. The Journal of Higher Education, 70(6), 670-686.

Yorke, M. (2009). „Student experience“ surveys: Some methodological considerations and an empirical investigation. Assessment \& Evaluation in Higher Education, 34(6), 721-739. 


\title{
Autoři
}

Mgr. Kateřina Juklová, Ph.D., Univerzita Hradec Králové, Pedagogická fakulta, Katedra pedagogiky a psychologie, Rokitanského 62, 50003 Hradec Králové, e-mail: katerina.juklova@uhk.cz

PhDr. Martin Chvál, Ph.D., Univerzita Karlova, Pedagogická fakulta, Ústav výzkumu a rozvoje vzdělávání, Myslíkova 7, 11000 Praha 1, e-mail: martin.chval@pedf.cuni.cz

Ing. et Bc. Stanislav Michek, Ph.D. Univerzita Hradec Králové, Pedagogická fakulta, Ústav primární a preprimární edukace, Rokitanského 62, 50003 Hradec Králové, e-mail: stanislav.michek@uhk.cz

PhDr. Jindra Vondroušová, Ph.D., Univerzita Hradec Králové, Pedagogická fakulta, Katedra pedagogiky a psychologie, Rokitanského 62, 50003 Hradec Králové, e-mail: jindra.vondrousova@uhk.cz

\section{Student evaluation of teaching using CEQ questionnaire: analysis of foreign experience}

\begin{abstract}
The review study aims to introduce one of the world's most widely used questionnaires of student evaluation of teaching, the Course Experience Questionnaire (CEQ). It introduces the theoretical background of the creation and modification of the questionnaire and on the basis of an analysis of 103 empirical and review studies describing experience with the creation, verification and use of the questionnaire in various educational contexts and in more than 20 countries brings evidence of its psychometric properties and possibilities of use. Finally, the potential contribution of the questionnaire to student evaluations in the current conditions of Czech higher education is discussed.
\end{abstract}

Key words: review, CEQ, questionnaire, perceived quality of teaching, learning experience, student learning theory, higher education 